\title{
“ESKIŞEHIR'DE LÜLETAŞI”
}

\author{
Doç. Dr. Ertuğrul ALGAN*
}

\section{ÖZET}

Lületaşı sepiyolit olarak bilinen bir madendir. Bu maden, "Eskişehir Taşı", "Aktaş", "Beyaz Altın” gibi adlarla da bilinir. Yabancı dillerin hemen hemen tümünde, Almanca' da “denizköpüğ̈̈" anlamına gelen "meerschaum” sözcüğ̈̈̈le anılır.

18. Yüzyılın başlarından itibaren Eskişehir ve çevresinin ve hatta Osmanlı İmparatorluğu'nun önemli ihraç maddelerinden biri lületaşıydı. En önemli ithalatçı ülke ise Avusturya idi. Bu yüzden lületaşı zaman zaman "Viyana Taşı” olarak da adlandırılmıştır. Söz konusu ihracat yaklaşık 300 yıl sürmüşı̈̈r. 1972 yılında çıkartılan bir yasa ile lületaşı ihracatı durdurulmuştur. Sektör 1980’lerden itibaren gerilemeye başlamış, günümüzde de durma noktasına gelmiştir.

Lületaşı sektörünün; talep azlığı nedeniyle yeni kuyuların açılmaması, yeni ustaların yetişememesi, yeni tasarımların ortaya çıkartılamaması, işletme vb. konularla ilgili sorunları vardır.

Sektörün canlandırılabilmesi için, yeni ustaların yetiştirilmesi ve yeni tasarımların ortaya konabilmesi için mutlaka girişimlerde bulunulması gerekmektedir. Bunun için sanat eğitimi veren lise ve üniversiteler devreye sokulabilir.

Anahtar Kelimeler: Lületaşı, Lületaşı Madenciliği, Lületaşı İşleme, Pipo-Ağılık Üretimi, Eskişehir.

*Anadolu Üniversitesi, Mimarlı ve Tasarım Fakültesi, Endüstriyel Tasarım Bölümü, Eskişehir/ TÜRKIYE ealgan@anadolu.edu.tr 


\title{
"Meerschaum in Eskişehir"
}

\author{
Assoc. Prof. Dr. Ertuğrul ALGAN*
}

\begin{abstract}
Meerschaum is a mine known as sepiolite. Also it is called as "Rock of Eskişehir", "White Rock" and "White Gold".

Beginning from the $18^{\text {th }}$ century meerschaum was one of the most important export goods of Eskişehir and the Ottoman Empire. And Austria was the import country of this mine, for that reason, it was also called as the "Rock of Wien". Export of meerschaum is continued about 300 years and the export of this mine was forbidden by law in 1972. Meerschaum industry in Eskişehir deteirorated at the beginning of 1980's andit is nearly to get lost in these days.

Because of the lack of demand there aren't any new meerschaum mines, lack of any new master carvers, lack of any new designs and problems about the bussiness.

There must be some attempts for the meerscum industry into the old days, such as training new masters, creating new designs, and this can be done by the art training schools.
\end{abstract}

Keywords: Meerschaum, Meerschaum Mining, Meerschaum Carving, Pipe Production, Eskişehir

* Anadolu University, Faculty of Architecture and Design, Department of Industrial, Eskişehir / TURKEY ealgan@anadolu.edu.tr 


\section{GíRiş}

Lületaşı, madencilikte sepiyolit olarak bilinen, genellikle beyaz, çok açık sarı veya pembekırmızı renklerde olan, oldukça güç koşullarda çıkartılan bir taştır. Madene sepiyolit adı, mürekkep balığının parlak ve gözenekli kemiği "sepio" ya benzemesi sebebiyle verilmiştir. Dünyanın birçok yerinde lületaşı ve sepiyolit çıkar, ancak en kaliteli lületaşları Eskişehir ve civarında bulunur.

Lületaşı madenleri "ocak" veya "kuyu” olarak adlandırılır. Lületaşı çıartan ustalar onu "patal”, "patal taşı" veya "aktaş" olarak adlandırır. Lületaşı, "Eskişehir Taşı” veya "Beyaz Altın” olarak da bilinir. Batılı ülkelerde ise dış görünümü denizköpügüne benzetildiği için, "meerschaum” olarak adlandırılmıştır.

Lületaşı, Eskişehir'den çıkartılmasına rağmen çok uzun yıllar "Viyana Taşı” olarak da adlandırılmıştır. Çünkü bu taşın en güzel örnekleri Viyanalı ustalar tarafından işlenmiş ve dünyaya Viyanalı ustalar tarafından tanıtılmıştır.

"Yaklaşık üç yüz yıldır emiciliği, hafifliği, beyazlık ve kolay işlenebilirliği dolayısıyla Dünyanın en cazip pipo malzemesi Eskişehir Taşıdır. Bu süre içinde Lületaşı pipolar Avrupalı koleksiyoncular tarafindan "Königin" - Kraliçe ünvanıla anıld,, prestij sembolü olarak kullanıldı, hediye edildi ve miras birakıldı" Ürersoy (1990).

Lületaşı bir çeşit kildir. "Sepiyolit... fillosilikat grubuna dahil kil mineralidir" DPT (2001). Kabaca iki gruba ayrılır. İlk grubunda, topraktan yumrular halinde çıkartılan lületaşı vardır. Diğeri ise tabakalı sepiyolit olarak adlandırılır ve sanayide kullanılır. Lületaşı, sepiyolit grubunun en kaliteli olanıdır ve pipo, ağızlık, süs eşyası, biblo vs. yapımında kullanılır. Eskişehir lületaşı, başta pipo ve ağızlık imali olmak üzere, tüm dünyada en fazla tercih edilen taştır. Bunun nedenleri arasında rengi gelir. Beyaz veya beyazımsı krem pipo ve diğer objelerin yapımında tercih edilen bir renktir. Somali, Madagaskar gibi ülkelerde çıkan taşların renkleri kahverengiye yakındır. Kaliteli Eskişehir lületaşları damar ve çatlaklar içermez, taşın rengi homojendir.

Eskişehir civarında çıkartılan lületaşı, gerek bilim insanlarının gerekse sanatçıların ve pipo kullanıcılarının dikkatini çekmiştir. Lületaşıyla ilgili ilk makaleler 1850'lerde yayınlanmaya başlamış, konuya ilişkin bilimsel çalışmalar 1900'lerde ve doktora çalışmaları ise 1920’lerde Alman üniversitelerinde yapılmıştır.

Lületaşı yumuşak bir madendir. Madenlerin sertlik dereceleri vardır. "Mosh Sınıflaması" olarak bilinen bu derecelendirme, 1 ile 10 arasındadır. En yumuşak madenler "1" seviyesindedir ve talkın sertlik derecesi "1" dir. "10" numarada ise elmas vardır. Bu sıralamada lületaşı 2-, 2,5 Mosh sertlik derecesindedir. Bu ise lületaşına kolaylıkla şekil verilebildiği anlamındadır. Lületaşının yoğunluğu porozitesine (gözenekliliğine) göre değişiklik gösterir.

Lületaşı ocaktan ilk çıktığında hafif nemlidir ve bu haliyle kolaylıkla şekil verilebilir. Kuruduğu zaman sertleşir ve işlenmesi zorlaşır. Kuru lületaşı su üzerinde yüzebilir. Bu yüzden işleme sırasında lületaşı ıslatılır. Islatıldığı zaman aşağı yukarı bir sabun sertliğine gelir. Bu da taşın işlenmesini kolaylaştırır. 
Lületaşının duayenlerinden Cihangir Aktaş Usta’yla yapılan bir görüşmede, Viyana’ya ihraç edilen lületaşlarının sandıklarından çıkartılıp bir havuza atıldığından, yüzen lületaşlarının pipo yapımı için ayrıldığından, batan taşların ise standartlarına uymadığı için geri gönderildiğinden söz edilmişti. ${ }^{1}$

Lületaşı zor koşullarda ve oldukça ilkel madencilik yöntemleriyle elde edilir. Lületaşı, zaman zaman derinliği 150 metrelere dek ulaşan, çoğu zaman yeraltı sularının bastı̆̆ı, motopomplarla suyun boşaltıldığı ve ciddi güvenlik önlemlerinin olmadığı kuyulardan çıkartılır.

Lületaşının artıkları ve tozları ise belli kimyasal maddelerle karıştırılarak preslenir ve ahşap pipoların astarlarında ve biblo yapımında da kullanılır.

"Lületaşı artıklarının öğütülerek, bazı kimyasal maddelerin yardımıyla, yeniden kullamılmasına ilk kez Avusturya'da başlanmıştır. Sun’i lületaşı denilen bu karışıma, bulucusunun adı verilerek "écume de Wagner" veya yapıldığı ülkenin adı verilerek, "écume de Autriche" denilmektedir. Dünya pazarlarında bu adlarla anılan sun’i lületaşlarının yapımında kullanılan kimyasal maddeler ve bunların bileșim oranları hakkında değişik görüsslere rastlanmaktadır” Akıncı (1968) ve Tekin (1972a).

Eskişehirde lületaşının işlenmesi sırasında ortaya çıkan atıklar ve lületaşı tozları tam anlamıyla değerlendirilmemektedir. Bazı firmalar lületaşı artıklarını öğütüp, alçıyla karıştırarak "lületaşı" adı altında bazı süs eşyaları vb. üretmektedir. Birçok kaynakta lületaşı ve türevlerinin uzay araçlarının ısı yalıtımında kullanıldığına ilişkin bilgilere rastlanmışı̧ı, ancak konuyu doğrulayacak herhangi bir bilimsel veriye ulaşılamamıştır.

\section{Dünyada Lületaşı}

Yanlış bir bilgi olarak, lületaşının dünyada sadece Eskişehir'de çıkartıldığı düşünülür. Dünyanın birçok ülkesinde hem lületaşı hem de sedimanter sepiyolit adı verilen, endüstriyel sepiyolit çıkartıldığı bilinmektedir.

"Dünyada lületaşı tipi sepiyolit yatakları, ülkemiz dışında başlıca Somali, Tanzanya, Kenya ve Meksika' da bulunmaktadır” DPT (2001).

Bu ülkeler dışında; Amerika Birleşik Devletleri, Avusturya, Avustralya, Çek Cumhuriyeti, Fas, Fransa, Hindistan, İran, İspanya, Macaristan, Madagaskar, Eski Yugoslavya (Sırbistan), Yunanistan’da (Thébes) lületaşı çıkartılır.

\section{Türkiye'de Lületaşı}

Türkiye’de farklı bölgelerde lületaşı çıartılır. Bunların başında Eskişehir gelir. Diğerleriyse, Konya/Yunak, Çanakkale, Bursa, Kütahya’dır. Çanakkale, Bursa ve Kütahya civarındaki ocakların işletilmesi de ekonomik değildir. Türkiye, 1980’lere dek, lületaşı üretiminde en önemli ülkeydi. Günümüzde lületaşı üretiminin Somali’ye kaydığı düşünülmektedir. Eskişehirden çıkartılan lületaşları en üst kalitededir. Bazı lületaşı ustalarıyla yapılan görüşmelerde, Konya,

${ }^{1}$ Cihangir Aktaş ile 08.03.2012 tarihinde yapılan söyleşi. 
Yunak'tan çıartılan taşların kalitesinin de iyi olduğundan söz edildi ancak Yunak’taki lületaşı ocakları henüz işletilmeye başlanmamıştır.

Eskişehir'de lületaşı dört farklı alandan çıkar. Bunlar kuzeyden güneye doğru sıralanacak olursa;

1. Eskişehir'in yaklaşık 40 km. kuzeydoğusunda yer alan Kayı bölgesidir. Bu bölgede, Başören, Beyazaltın (Sepetçi), Gündüzler, Margı, Söğütçük ve Taycılar köyleridir. En fazla ürtetim bu bölgede yapılmaktadır/yapılmaktaydı.

2. Eskişehir’e yaklaşık $40 \mathrm{~km}$. uzaklıkta ve yine kuzeydoğu yönünde yer alan Gökçeoğlu’nda lületaşı yatakları yaklaşık $1 \mathrm{~km}^{22}$ lik bir alana yayılmıştır. Bozkurt (1989)

3. Gökçeoğlu bölgesinin güneyinde yer alan Sarısu Bölgesi’nde İmişehir, Türkmentokat, Karatepe köyleri bulunur. Yüzlerce yıldır kazılan ocakların önemli bir kısmı TürkmentokatKaratepe köyleri arasında yer alır. Bölge doğu-batı yönünde $5 \mathrm{~km}$. Kuzey-güney yönünde ise yaklaşık 3 km. lik bir alana yayılmıştır. 2011 yılında kurulan "Lületaşı ve Diğer Değerli Taşlar İşletme Kooperatifi” bölgede yeni bir kuyu açmıştır. Ancak üretim eski kuyular temizlenerek yapılmaktadır.

4. Nemli bölgesi madenleri, şehrin güney batısında, Eskişehir-Kütahya karayolunun yaklaşık 20. kilometresi civarında yolun batı kısmında yer alı. Buradaki ocaklar çok uzun yıllardır kullanılmamaktadır. Bölgede bulunan manyezit maden sahasını dolaşırken kepçelerle açılmış alanda yüzeye yakın, yaklaşık ceviz büyüklüğ̈̈nde lületaşı parçalara rastladık. Bozkurt (1989) Taşlıgil vb.(2011).

“Von Diest, 1886'da Eskişehir'de rastladığı Avusturyalı lületaşı alıcısı Herr Conh'dan aldığı bilgiye göre, dünyanın hiçbir yerinde Eskişehir’ deki ocakların benzerinin olmadığını kaydeder... O tarihte ocaklarm bulunduğu bölge, Kaliforniya' daki altın aranan topraklar gibidir ve kötü çalışma koşulları ve kendine özgü kuralları ile sanki ayrı bir ülke görünümündedir. 1890’ da Eskişehir' e gelen Naumann' da aynı koșulları saptar ve ocaklarda her milletten insanın, Çerkezlerin, Ermenilerin, Dürziler ve Acemlerin çalışığını bunların çoğunun kanun kaçakları olduğunu yazar. Aynı kötü çalışma koşullarından ve bölgedeki inanılmaz kalabalık ve canlılıtan Körte’ de söz etmektedir. Naumann' in anlattığına göre, Porsuk nehrinin yakınındaki kuyular $70 \mathrm{~m}$. kadar derinliktedir. Dağlara doğru yaklaştıkça bu derinlik azalır. Sepetçi' deki en derin kuyu o tarihte 60 metredir. Bu derinliğe rağmen hiçbir tertibat yoktur. Yalnız kuyuların kenarına basamaklar oyulmuştur. En fazla işletme Sarısu ocağındadır ve burada toprak elek gibi oyulmuştur...” Albek (1991).

Eskişehir'de lületaşı ocakları hep dikkat çekici olmuş ve Osmanlı İmparatorluğu'nda hükümet bu taşın üretimiyle ilgi oldukça ciddi tedbirler almıştı.

\section{Kısa Tarihçe}

Lületaşının ilk kez ne zaman kullanıldığına ilişkin bilgiler yok denecek kadar azdır. Yapılan arkeolojik çalışmalar bu madenin M.Ö. 2000'lerde kullanıldığına ilişkin bilgiler vermektedir. 
1999 - 2002 yılları arasında, Eskişehir Arkeoloji Müzesi Başkanlığında, Doç. Dr. A. Nejat BİLGEN’in, Alpu Ovası̉nda yer alan Çavlum Köyü’nde yapmış olduğu kazıda lületaşından yapılma bir adet damga mühür bulunmuştur. Söz konusu mühür, kazıyı yöneten Bilgen tarafından M.Ö. 18.yüzyıl ortalarına tarihlenmiştir. Bu da kaba bir hesapla bize mührün 3750 yıllık olduğuna dair ipuçları verir. "Kazı çalışmaları sırasında ele geçen eserlerden en ünik olanı, lületaşından yapılmış bir adet damga mühürdür... Çavlum Nekropolündeki lületaşı mühür ise sekiz yaşında bir çocuğa ait, mezar numarası 50 olan taş sanduka mezardan ele geçmiştir” Bilgen (2006) .

Bilgen'den önce Demircihöyük kazılarında da lületaşından yapılmış bir obje bulunmuştur. Söz konusu objenin ne amaçla kullanıldığına ilişkin bilgi yoktur.

Lületaşından söz eden ilk yazılı kaynak, 1173 yılında Anadolu'yu gezen, Ali Bin Abibakr Al-Haravi’nin yapıtıdır. "Haravi Eskişehir'den 'ìlâm ülkelerinin bir köşesinde, küffar sınırında bir acayip şehir' diyerek burada işletilmekte olan lületaşından ve buradaki ılıcadan söz etmiştir” (Togan, 1949: 318-319). Ancak Al-Haravi lületaşının ne amaçla kullanıldığına dair bilgi vermez. Cahit Bilim buna: “...Anadolu Selçukluları Dönemine denk gelen bu tarihte tütün ve tütün içme söz konusu olmadığından bu maden su yolları, su kapları, çeşme gibi su ile ilgili vb. aletler yapımında kullanılmış olsa gerekir" biçiminde yorum getirir Bilim (2001).

Lületaşı tütün endüstrisine bağlı olarak önem kazanmıştır. Avrupa'da tütün kullanımı yaygınlaştıktan sonra farklı materyallerden pipo ve ağızlıklar yapılmıştır. Lületaşı tüm malzemeler arasında en ilgi çekeni olmuştur. Osmanlı İmparatorluğu zamanında, lületaşı madenciliği, ocak açma, alım satım, ihracat, hükümet tekeli altında yapılıyordu. Ocaklardan çıkartılan taşlar temizlendikten sonra Mihallıçık ve Eskişehir'deki depolarda toplanıyor ve bu işle uğraşan tüccarlara satılıyordu. Bu özelliğiyle lületaşının Osmanlı İmparatorluğu’nun ilk ihraç maddesi olduğunu söylemek yanlı̧s olmayacaktır.

“A. Reinhardt Eskişehir'le İznik arasındaki kervan yoluna "Lületaşı Yolu” adını vermiştir. O tarihlerde İznik'ten İstanbul'a getirilen lületaşları Belgrad ve Budapeşte’ye gönderiliyor ve oradan da Viyana’lı tüccarları eline geçiyordu” Tunçdilek, (1955).

Texier, 1830 yılında yayımlanan kitabı “Küçük Asya’ da, lületaşı ve çıkartıldığı bölgenin jeolojisinden uzun uzun söz eder.

"Kalınlı̆̆ bir metreyi geçmeyen bu ikinci balçık tabakasının altında, daha zengin ve daha verimli bir başka damar vardır. Bu damar, halk dilinde "deniz köpüğü" denilen ve maden bilimi (mineroloji) terimi olarak silicate de magnésie adı verilen lüle Avrupa'da bilinmektedir. Bunun bilinen damarları çok az, yani biri Macaristan'da ve diğeri Yunanistanin Thébes şehri yakınında olmak üzere iki üç yerden ibarettir. Fakat bu Mihalıç’taki cinsi, tereddütsüz en güzeli, en safı ve en beyazıdır.

Bu madde, devaml ve düzenli tabaka oluşturmaz. On beş-yirmi metre derinliğinde kuyular açılarak çıkartılır ve smectique denilen balçı tür içinde yuvarlak taş halinde serpilmiş bulunur. Bundan bir ayak küp boyutunda bulunduğu çok nadirdir. Ham çıkarıldığı zaman üzeri yumuşak ve topraklı bir kabukla kaplıdır ve çoğunlukla kütleler, çok düzensiz şekildedir” Texier (2002). 
Lületaşının pipo imalatında ilk kez ne zaman kullanıldığına ilişkin kesin bilgiler yoktur. Var olan bilgiler ise, yanlış tercümeler, yanlış yorumlar dolayısıyla daha da karmaşık hale gelmiştir. Bu yalnızca Türkçe yazılarda değil, pipo ve tütün üzerine tüm dünyada referans kabul edilecek yazar ve kitaplar arasında da çelişkiler ve bilgi kirliliği yaratmaktadır Benjamin Rapaport’un "Collecting Antique Meerschaum Pipes" adlı yapıtındaki bilgilerin doğru olduğu varsayılabilir. Rapaport "meerschaum (denizköpügü)" sözcüğünün 1475'lere dek uzandığından ve bu maddenin daha öncelerden de bilindiğinden söz eder. Rapaport (1999)

İlk lületaşı piponun öyküsü, Osmanlı Sultan’ı III. Ahmed'in (1673-1736) Macar kontu Andrássy'e 1723 yılında hediye ettiği iki lületaşı parçasıyla başlar. Kont bu taşları becerikli bir ayakkabı ustası olan Karl Kovács’a (Karol Kowates) verir. Kovács bu taşlardan biri kendisine, diğeri de Kont’a olmak üzere iki pipo yapar.

“...Kovács Károly (ahşap işçisi, lületaşı piponun mucidi, Macaristan doğumlu) on sekizinci yüzyılın ortalarında Peşte'de yaşamıştır (1750) ve ilk lületaşı pipoyu, o günün Avusturya Dışş̧̧leri Bakanı olan atalarından birinin Türkiye'den hediye olarak aldığı taş ile yapmıştır, dolayısıyla daha sonra geniş ölçeklere yayılacak olan bir endüstrinin mucidi olarak düşünülebilir. Kovácsin yaptı̆̆ı pipolar Macar Ulusal Müzesinde muhafaza edilmektedir". Rapaport (1989)

Lületaşının Osmanlı’nın ilk ihraç ürünlerinden bir tanesi olduğundan söz edilmişti. Lületaşının 1650'li yıllardan beri ihraç edildiği düşünülmektedir. Tütünün Avrupa’ya 1518 yılında geldiği göz önüne alınırsa, 1650'lerden itibaren lületaşının tütün içmede kullanılan pipo imalatında kullanıldığı da düşünülebilir. Çok ilginçtir lületaşı Anadolu’da, Osmanlı İmparatorluğu sınırları içinde çıkartılmasına rağmen, tütün içiminde lületaşından yapılma pipolar dışında, Tophane Lüleleri kullanılmıştır. Lületaşı gibi bir malzeme bilinirken ve çok önemli miktarlarda ihraç edilirken Osmanlıda lületaşının hemen hemen hiç kullanılmamış olması biraz şaşırtıcı gelmektedir. Belki o döneme göre önemli bir ihraç maddesi olması ve karşılığının altın olarak ödenmesi ve pahalı bir malzeme olması, yurt içinde kullanımını engellemiş olabilir.

\section{Lületaşının Üretilmesi ve Pazarlanması}

Türkiye bilindiği gibi maden zengini bir ülkedir. Ancak bazı madenlerle ilgili çalışmalar henüz tamamlanabilmiş değildir.

"Ülkemizde lületaşı, yüzylllardan beri bilinen ve geleneksel ihraç ürünlerimizden olan bir mineral olmasına karşın, sedimanter oluşumlu, tabakah tip sepiyolit yataklarına yönelik araştırmalar son yıllarda başlatılmış ve kullanım alanlarının tespitine yönelik teknolojik çalışmalar yürütülmüştür. Lületaşıyla ilgili rezerv belirleme çalışmaları ise M.T.A. tarafindan 1963 yılında başlatılmıştır. Bu çalışmadan çıkan sonuçlara göre Sarısu bölgesinde yaklaşık 600.000 sandık lületaşı olabileceği düşünülmektedir” MTA (1982).

Lületaşı ocakları sulu ve kuru ocaklar olarak ikiye ayrılır. Lületaşı ocağı açmak için önce lületaşının bulunabileceği yer kazılmaya başlanır. Kazma işlemini kuyucular yapar ve onlar nerede lületaşı bulunabileceğini hissederler(!). Lületaşı ocakları bölgelerde yaşayan köylülerden oluşan ocakçılar tarafından yapılır. Ocakçllar neredeyse beş-altı kuşaktır bu işi yapan ailelerden çıkar. 
Lületaşı ocakları neredeyse üç yüz yıldır aynı yöntemlerle kazılır. Lületaşının toprak altında nerede bulunacağı çoğu zaman bilinemez. Ancak topraktaki bazı emarelere bakılarak tahmin edilebilir. Lületaşı toprağın farklı derinlik ve katmanlarında bulunabilen bir madendir. Bazen hemen yüzeye yakın, bir kaç metre derinlikten çıkartılabilirken bazen 150 metre derinliğe dek inmek gerekebilir. Lületaşı kırmızı renkli bir toprak içinde bulunur. Diğer madenlerde olduğu gibi lületaşı damarlar halinde değildir. Toprağın içinde belli büyüklüklerde yumrular halinde bulunur. Lületaşının bulunduğu derinliğe gelindiği zaman yatay galeriler açılır ve lületaşı toprağın içinden toplanır. Çoğu zaman lületaşı ocaklarından su çıkar, bu su motopomplarla boşaltılarak çalışmalara öyle devam edilir. Bazen bu galerileri madencilerin yaşamlarını tehlikeye düşürecek biçimde su basar ve çalışmalar zorlaşır.

“Geleneksel bir lületaşı üretim kuyusunun görünümü şöyledir: $60 x 160 \mathrm{~cm}$. boyutlarında açılan kuyuları ağzına basit, ağaçtan bir çıkrı yerleştirilir. Kuyu dibinde kazı sonunda meydana gelen pasa, bu çıkrı̆ga bağh 15-20 litre hacimli bir kova veya torba ile yukarı çekilir. Kuyunun birbirine yakın geniş yüzeylerinde, karşıllklı olarak, 10-15 cm. derinlikli $150 \mathrm{~cm}$. aralıklı oyuklar açılır ve çıkrıktan kuyu tabanına dek bir de kılavuz ipi sarkitılli. Isş̧̧iler söz konusu oyuklara basarak, kuyu duvarlarına dirseklerini dayayarak, kılavuz ipine tutunarak kuyulara inip çıkmaktadırlar” MTA (1982).

Lületaşı madenciliği neredeyse yüzyıllardır hiç değişmeden günümüze dek gelmiştir. 1960'lar sonrasında ocakların modernleşmesi adına yapılan “çıkrık yöntemi”nden farklı olarak "skip yöntemi” adı verilen ve ocağın ağzına konan elektrikli bir vinç ve kazma işleminde zaman zaman kompresör ve ocaklarda biriken suyu dışarı atmak için kullanılan motopomplardır.

"En önemli kazıcı alet tek tarafl, sivri uçlu, kısa saplı bir kazmadır. Bundan başka, sert klsımların gevşetilmesinde küçük çelik kamalardan da faydalanılır. Bugüne kadar bölgede yapılmış bulunan milyonlarca metreküp tutarındaki hafriyat, tamamen, patlayıcı kullanilmadan, insan gücü ile yapılmıştır” MTA (1982).

Bir lületaşı ocağı açmanın aşamaları şunlardır.

1. Kuyucular lületaşı çıkma olasılığı olan bölgeyi tespit eder. "Geleneksel lületaşı işletmeciliğinde, daha çok deneyime önem verilir. Ocaklarda uzun süre alışmış madenciler, deneyimlerine dayanarak, bazı jeolojik ve litolojik gerçeklerin pratik önemlerini kavramışlardır...söz konusu geleneksel işletme kuyularına, alışmış iş̧ilerden başka kimse giremez. Bu yüzden, yeraltı üretim faaliyetlerinin yerinde incelenmesi, çalışmaların takibi ve kontrolü imkan dahilinde değildir" MTA (1982).

2. Bu bölgede yaklaşık 1.5-2 metre çapında bir kuyu açmaya başlarlar. Kuyu açma biçimi aynı su kuyusu açmaya benzer. Bu kuyunun derinliği ilk etapta 20-25 metre civarındadır.

3. Kuyunun ağzına, kuyu açılırken çıkartılan toprağın çıkartılması, madencilerin kolaylıkla inebilmeleri ve taş dolu kovaları yukarı çekebilmeleri için "ayı bacağı" adı verilen bir çıkrık konur. Bu çıkrık ahşaptan olur. Son yıllarda açılan kuyulara profil demirden yapılmış çıkrık konmaktadır. 
4. Kuyuların duvarlarına ayakların basılarak oyuklar açılır. İşçiler bu oyuklara basarak ve çıkrıktan kuyunun dibine sarkıtılan urgana tutunarak kuyuya inip çıkarlar. İşçilerin ayaklarını basmaları için oluşturulan bu oyuklar "basak" olarak adlandırılır.

5. Dikey kuyuya yatay galeriler açılır. Bu yatay galerilerin içinde madenciler bazen diz çökerek çalışmak zorunda kalırlar. "Lületaşı istihsalinde kazmacılar, daima dizleri üzerinde oturarak çalışırar. Bu sebeple galeri yükseklikleri $120 \mathrm{~cm} .140 \mathrm{~cm}$. den daha fazla değildir. İşçi, dizleri üzerinde oturmuş durumda iken daha isabetle, aynadaki belirli bir noktaya kazmayı vurabilir... ekonomik değer taşıyan lületaşı yumruları, yantaş içinde seyrek olarak dağılmış olabileceği gibi, birbirlerine girift durumda da bulunabilirler. Bu şartlar, lületaşı üretiminin patlatıcı maddeler, mekanik kazı aletleri ve makineleri kullanarak yapılmamasının nedenlerini ortaya koymaktadır" MTA (1982).

6. Yatay galeriler derinleşirse, galerinin tavanını taşıması için "topuk" adı verilen sütunlar birakılır.

7. Kuyu açılırken belli sırada toprak katmanlarının gelmesi gereklidir. Eğer herhangi bir katman çıkmazsa kuyunun açılmasından vazgeçilir ve yeni bir kuyu için deneme yapılır. Katmanlar sırasıyla şöyledir: a) Alüvyon toprak, b) Akşemil adı verilen beyaz renkli bir toprak katmanı c) Kum, d) Açık kahve rengi toprak, (deve tüyü toprak), e) Çakmaklı kum adıverilen tabaka, f) Kırmızı killi toprak, g) Lületaşı yumrularının bulunduğu sert toprak. Tekin (1972)

8. Taş olan tabakaya ulaşıldıktan sonra, kısa saplı kazmalar ve kamalar kullanılır. Taş olan tabaka "yolak" olarak adlandırılır. Söz konusu kazmalara ise "külünk" denir. Yolak yukarı doğru giderse, "çöğdü” denir. Aşağı doğru inerse, "battı” olarak adlandırılır. Çıkartılan taşlar öz sularını kaybetmemeleri için, gün sonuna dek ocakta bekletilir. Günün son işlemi olarak maden işçileri ocakta taşın kaba temizliğini yaparlar.

Lületaşının çıkartılması hep ilgi çekmiş, gezginlerin notlarında yer almıştır. Bunlardan biri de Cuinet'tir. Cuinet 1890'larda, Eskişehir civarında yoğunlaşmış olan 1770 lületaşı kuyusunun işletildiğini kaydetmekte ve taşın çıkarılışını şöyle tarif etmektedir:

"Bir ustabaşı 15 kadar işçiyle bir metre karelik bir alanı kazma ile kazdırır. Lületaşının varlığın işaret eden kırmızı toprak çıkıncaya kadar kazılır. Bu derinlik çok değişiktir. Bazen yüzeyden birkaç metre aşağıda rastlanabilir. Genellikle 20 metreye kadar kazmak gerekir. Hatta bazen 60 metreye kadar inilebilir. Lületaşı kırmızı toprak içinde düzensiz yumrular halinde görülür. Çoğu bir ceviz ya da elma büyüklüklerindedir. Lületaşı kapsayan kırmızı toprağa gelince, işçiler yatay iki galeri açarlar. Bu galerilerin bazılarının uzunluğu 400 m. kadar uzunluktadır. Hiçbir plan gözetilmeden açıldıkları için bazen başka galerilerle kesişirler. Isş̧iler bu galerilerde, gece ve gündüz petrol lambalarının ışı̆̆ında çalışırlar. Taş çıkarıldıkça madencilerin barakalarına yı̆̆ı̆lır. Eskişehir'den gelen Lüleciler (ki bunlar o tarihte 150 kişi kadardır) Cuma pazarında bunları alırlar, taşları üstünün pisliğiyle Eskişehire taşırlar. Burada taşlar yıkanır, çakıyla hafifçe yontularak temizlenir. Bu kaba temizlik işiyle 1000 kadar iş̧̧i uğraşır. Sonra taşlar büyüklüklerine göre 4 sinıfa ayrllp sandıklara doldurulur, birbirlerine çarpıp kırılmamaları için aralarına pamuk konulur. Bunlar 12 komisyoncu tarafindan Viyana’ya gönderilir" Cuinet’ten Aktaran Albek (1991). 
Lületaşı ocakları veya kuyuları kuru kuyular ve sulu kuyular olarak ikiye ayrılır. Sulu kuyuların tabanlarında su birikir veya su çıkabilir. Bu su çalışmayı zorlaştırır ancak söz konusu kuyulardan çıkartılan lületaşı daha kaliteli ve makbuldür. Söz konusu kuyulardaki su güçlü motopomplarla dışarı atılır.

Bir lületaşı kuyusunda üç (3) ile beş (5) arası işçi çalışır. Kuyunun ağzındaki "ayı bacağı” adı verilen çıkrık başında 1-3 işçi çalışır. Bunların görevi hem aşağıda çalışan kazmacılarla irtibatı sağlamak hem de kuyudan çıkan ve "pasa" adı verilen toprağı yüzeye çıkartmaktır. Kuyularda 2 veya daha fazla kazmacı çalışabilir. Kazmacılık çok önemlidir. Onlar toprağın durumu ve rengine göre lületaşına ulaşırlar. Ocaktan çıkartılan her taş boyutlarına bakılmaksızın kullanıma sunulur. Çünkü en küçük parçadan bile yapılabilecek objeler vardır.

2011 yılında kurulan "Lületaşı ve Diğer Değerli Taşlar İşletme Kooperatifi", Türkmentokat Köyü yakınlarında, sondaj makineleri kullanarak iyi bir kuyu açmıştır. Kuyuyu gidip görme olanağımız oldu. Ölçümlerimize göre kuyu yaklaşık 40 metre derinlikteydi ve dibinde birikmiş su vardı. Ancak, kuyu geleneksel standartlarda olmadığı için yeryüzüne paralel galerilerin açılmasında sorun yaşanmıştı ve kuyudan lületaşı çıkabileceğine ilişkin bir iz yoktu. Bölgede konuştuğumuz, geleneksel yöntemlerle madencilik yapan kişiler söz konusu kuyudan lületaşı çıkabileceğini söylemişlerdir.

Lületaşı ocaklarında herhangi bir güvenlik tedbiri alınmadığından söz edilmişti. Kuru ocaklarda çok ciddi sorunlar yaşanmasa da, sulu ocaklarda sorunlar vardır. Kuyuların dibinde biriken sular hem çalışmayı zorlaştırır hem de hayati tehlikeler oluşturur. Yaşlı ocakçılarla konuşulduğunda; "Birden bire kuyuyu su basar, kendini dışarı zor atarsın...”cümlesi sıkça duyulur.

\section{Lületaşının Sınıflandırılması}

Lületaşının kalite açısından sınıflandırılmasında bilimsel kıstaslar kullanılmaz. Sınıflama yüzyılların getirdiği alışkanlık ve geleneklere göre yapılır. Lületaşının sınıflandııılmasında, boyut, renk, taşın işlenmesiyle ilgili kalite vb. gibi kıstas ve bilgiler devreye girer.

Lületaşının en kalitesizden kaliteliye kadar olan sınıflandırılması şöyledir:

1. Cilız

2. Dökme

3. Orta

4. Daneli

5. Pamuklu

6. Birimbirlik

7. Siramalı

Bunlar dışında "omuzlama" ve "budama" adı verilen ancak çok ender çıkan çok büyük parçalar da çıkar. "Çıkartılan taşların ağırlı̆̆ı ortalama 100 gr. ile 2000 gr. arasında değişmektedir. Ender 
olarak daha büyük taşlar da çıkmaktadır. Bu isle uğraşanlar, bugüne kadar çıkarılan taşların en büyügüüün $192 \mathrm{~kg}$. geldiğini ve bu lületaşının, büyük bir törenle Avusturya’ya götürülmüss olduğunu söylemektedirler (yaklaşık 250 yıl önce)" Tekin (1972). Bu bilgi Cengiz Tekin’in "Lületaşı Sektörünün Ekonomik Analizi” adlı doktora çalışmasında yer almaktadır. Ayrıca lületaşı ustaları arasında kulaktan kulağa dolaşan bir efsane biçimindedir. Ustalarla yapılan görüşmelerde, "odun sobası büyüklüğündeymiş...” gibi belli bir ölçüye dayanmayan tanımlamalarla da karşılaştık.

\section{Lületaşı Üretim Miktarları}

Eskişehir ve çevresindeki lületaşı üretim miktarlarıyla ilgili bilgiler oldukça yetersizdir. Bunun nedenleri başında, kaçak ocak işletmeciliğinin devam etmesidir. Lületaşı maden sahalarının ruhsatları belli kişi ve şirketlerin elindedir. Ancak lületaşı madenciliğini bilen bölgede yaşayan köylülerdir. Ruhsat sahipleri sadece ellerinde ruhsatı tutmakla yetinmektedir. Köylüler olmadan ruhsat sahiplerinin lületaşı çıartmaları neredeyse olanaksızdır. Bu yüzden ya kaçak kazılar yapılmaktadır veya eski ocaklar temizlenerek kaçak lületaşı çıkartılmaktadır. Resmi olmayan bir çalışma biçimi de köylülerin ruhsat sahibiyle anlaşarak yaptıkları kazılardır. Ham lületaşını satın alan ve işleyenlere satış yapan madenci köylüler, herhangi bir fatura veya resmi bir belge verememektedir. Üretilen lületaşı objelerin ihracı söz konusu olduğunda resmi belgeye gerek duyulmaktadır. Resmi belge ise "müstahsil makbuzu” vb. ile sağlanmaktadır.

Türkiye Ekonomisinde Lületaşı adlı kitapçıkta 1905 yılından 1958 yılına dek olan lületaşı üretimi bir liste olarak verilmiştir. (Liste kısaltılarak verilmiştir. EA.)

\begin{tabular}{|c|c|}
\hline Ylllar & Lületaşı İstihsâli (Sandık) \\
\hline 1905 & 5.075 \\
\hline 1925 & - \\
\hline 1930 & 380 \\
\hline 1935 & 694 \\
\hline 1940 & 255 \\
\hline 1945 & 817 \\
\hline 1950 & 328 \\
\hline 1955 & 882 \\
\hline 1958 & 1.620 \\
\hline
\end{tabular}

Tablo 1: Yillara göre lületaşı üretimi (1905-1958)

Yukarıdaki liste kanımızca gerçekçi görünmemektedir. Çünkü söz konusu yıllarda sadece Viyana'da 500'den fazla pipo imalatı yapan firma vardı. Bu sayıya Almanya -ki önemli bir lületaşı pipo üretim merkeziydi-, Fransa, İsviçre, Hollanda vb. ülkelerdeki imalathaneler dâhil değildir.

Basit bir hesapla şöyle söylenebilir: Bir sandıkta yüz adet pamuklu taş bulunur. Örneğin 1955 yılında 882x100=88200 parça taş eder. Bunun 400 firmaya paylaştırıldı̆̆ 1 düşünülürse, firma 
başına 220 adet yaklaşık 2 sandık taş düşer. Oysa söz konusu yılda, elimizde kesin sayı olmasa da, her firmanın binlerce pipo ürettiği bilinmektedir.

\begin{tabular}{|c|c|}
\hline Ylllar & Üretim Miktarı (Ton) \\
\hline 1964 & 70 \\
\hline 1965 & 50 \\
\hline 1966 & 29 \\
\hline 1967 & 44,7 \\
\hline 1968 & 61 \\
\hline
\end{tabular}

Tablo 2: Yillara göre lületaşı üretimi (1964-1968)

01.02.2010 tarihinde güncellenen Türkiye Maden Rezervleri listesine göre de 1.483 .670 sandık iyi ve orta kalitede lületaşı rezervi bulunmaktadır.

2003-2009 yılları arasında 721, 3 ton üretim yapılmıştır ve yıllara göre yapılan ihracat dağılımı şöyledir:

\begin{tabular}{|c|c|}
\hline Ylllar & İhracat Miktarı (\$) \\
\hline 2003 & $127.999,33$ \\
\hline 2004 & $100.152,99$ \\
\hline 2005 & $116.268,11$ \\
\hline 2006 & $88,017,45$ \\
\hline 2007 & $21.017,45$ \\
\hline 2008 & 917,44 \\
\hline
\end{tabular}

Tablo 3: Yillara göre ihracat miktarları (2003-2008)

Lületaşının ham olarak dış satımı 1960 yılında izne bağlanmış, 1972 yılından sonra da taşın işlenmemiş olarak dış satımı tümüyle yasaklanmıştır. Bu yasaklar Eskişehir'de lületaşı işçiliğinin canlanmasını ve çok sayıda atölyeler açılmasını sağlamıştır.

\section{Lületaşının Plastik Özellikleri}

Lületaşı kolay işlenebilen bir malzemedir. Yukarıda da değinildiği gibi, ocaktan çıktığı zaman nemlidir, içinde su barındırır ve bir bıçakla şekil verilebilecek durumdadır. Aşağı yukarı bir sabun sertliğindedir. Ocaktan çıkartıldıktan sonra malzeme özsuyunu kaybeder ve sertleşmeye başlar. Lületaşı porozitesi (gözenekliliği) fazla bir malzemedir ve suyu kolaylıkla absorbe eder. Bu özelliği dolayısıyla bekleme veya işlenme sırasında özsuyunu kaybeden malzeme tekrar suya atıldığı zaman suyu absorbe eder ve eski yumuşaklığına kavuşur. Ham veya işlenen malzeme yıllarca beklese bile söz konusu işlemden sonra tekrar ve kolaylıkla işlenecek yoğunluğa ulaşır. $\mathrm{Bu}$ da malzemeyle çalışan sanatçıya kolaylıklar sağlar.

Lületaşının en önemli özelliklerinden biri, sigara dumanı, nikotin ve benzerlerini kolaylıkla 
absorbe etmesidir. Dolayısıyla bir süre kullanılan lületaşı malzeme, ortamda sigara dumanı vb. varsa sararmaya başlar ve uzun süreli kullanımlarda bu renk kehribar ve hatta kahverengiye dek ulaşır. Malzemenin bu özelliğini fark eden lületaşı işleme ustaları, son yıllarda özellikle takı yapımında kullandıkları lületaşı parçaları, gazete, renkli kâğıtlarla sararak yakmaktadırlar. Böylelikle dumandan etkilenen lületaşı malzeme renk değiştirmektedir. Aynı biçimde malzeme üzerine ebru, minyatür vb. uygulamalar da yapılmaktadır. Söz konusu çalışmalar laboratuvar vb. ortamlarda yapılmamıştır, yalnızca deneme yanılma ile bulunmuş renklendirme yöntemleridir. Laboratuvar koşullarında, farklı malzemelerle yapılacak çalışmalarda çok farklı sonuçlara ulaşmak mümkün görülmektedir.

Geleneksel çalışma yöntemlerinde, malzeme işlendikten sonra, zımparalanır, keçe ile pürüzleri yok edilir ve parafinlenir. Parafinleme işlemi, malzemenin absorbsiyon özelliğini azaltır. Sözü edilen son işlemlerden sonra, lületaşı üzerinde değişiklikler yapılmak istenirse parafin tabakasının kaldırılması gerekir. Bu işlemde belli kimyasal maddeler kullanılarak yapılabilmektedir.

Çalışmanın farklı yerlerinde söz edildiği gibi, lületaşı yoğun olarak, sigaralar için ağızlık, pipo üretiminde kullanılmıştır. Ancak Avusturya, Hollanda ve diğer ülkelerdeki müzelerde lületaşından yapılmış küçük heykelciklere de sergilenmektedir. 1990 yılında düzenlenen "Beyaz Altın, Lületaşı Festivali’ne” sanatçılar davet edilmiş, söz konusu sanatçılar lületaşı heykeller yapmıştır. Söz konusu heykeller “Odunpazarı Belediyesi, Lületaşı Müzesi”nde sergilenmektedir.

Lületaşının sanat objeleri oluşturmada az kullanılmasının nedenlerinin başında ocaklardan çıkartılan parçaların küçük olması gelmektedir. Lületaşı boyutlarını belirlemede kullanılan ve bir standart sayılabilecek olan ölçü "pamuklu" biçiminde adlandırılır. Söz konusu boyut metrik ölçülerden ziyade göz kararıyla belirlenir ve ortalama bir yetişkinin yumruğu büyüklüğündedir. Dolayısıyla heykel sanatçıları ve diğer sanatçılar, özel olarak bu boyda bir eser üretmeyeceklerse lületaşına ilgi göstermemektedirler. Randımanlı çalışan ocaklar olmadığı için de büyük parçaların çıkartılması ekonomik açıdan da mümkün olamamaktadır.

\section{Avrupa ve Türkiye'de Lületaşı İşlemeciliği}

Kristof Kolomb 1492 yılında Amerika’ya ulaştı, Amerikảnın yerlileri olan Kızılderililer Kolomb’a bu kıtadan ayrilırken hediye olarak kurutulmuş yapraklar vermişti. Söz konusu yapraklar, sonraki yıllarda ve hatta günümüzde tüm dünyayı etkileyecek, tiryakiliklere neden olacak olan tütündü. Batıda tütüne "tobacco" adı verilir. Bu ad bir yanlış anlaşılma sonucunda ortaya çıkmıştı. Amerika yerlileri, içine tütün doldurdukları mısır yapraklarını veya hasır otlarını "tobagos" olarak adlandırıyorlardı. Dolayısıyla yerli dilinde, bu sözcük tütün değil ancak tütün içilen araç anlamındaydı.

1700'lerde ülkelerde tütün tekelleri oluşmaya başladı. 1700’lerin ikinci yarısında ise başta Avusturya olmak üzere Avrupa’nın büyük kentlerinde, "keyif veren maddeler" arasında yerini aldı. Tütünle birlikte sosyal yaşama farklı objeler de girmeye başladı. Bunlar arasında, tütün içmeye yarayan pipolar, lüleler de vardı. Bunlar yalnızca tütün kullanımı için değil aynı zamanda birer prestij objesi olarak da algılanmaya ve kullanılmaya başlandı. 
Avrupa'da ilk pipolar bir tür çömlek çamurundan yapılıyordu ve "kil pipolar" olarak biliniyordu. Bunların benzerleri Osmanlı İmparatorluğunda da kullanılmıştır ve "lüle" olarak bilinirdi. 17. yüzyılın sonlarında ahşap pipolar yapılmaya başlandı. Ancak her ahşap pipo yapımına uygun değildi.

Takip eden yıllarda tümüyle tesadüflere bağlı olarak çok farklı bir pipo malzemesi, lületaşı pipo yapımında kullanılmaya başlandı.

"Pipo yapmak için keşfedilmiş en zarif materyallerden biri lületaşıdır. Bu özel materyalin doğuşu uzun süre bir giz olarak kalmıştır... İlk bakışta lületaşının mat, süt gibi beyaz yüzeyi fildişini andirur" Fellner ve Thiel, (2009).

Batıda üretilen pipoların önemli bir kısmında oryantalistik motifler vardı. Bunda özellikle Osmanlıda tütün içme ve lüle kullanma işinin bir törene dönüşmesi, kıraathane, kahvehane kültürünün oturmuş olması, batılı gezginlerin anılarında, notlarında tütün kullanma geleneğinden söz edilmesi olabilir.

Almanya’ da Ruhla ve Lemgo kentleri lületaşı pipoların seri üretimlerin ilk merkezleri oldu. Viyana ise 19. Yüzyılda adından söz ettirmeye başladı. Viyana’da başlayan üretimlerden sonra lületaşı pipolar Avrupa’da moda haline geldi ve birer itibar malzemesine ve aynı zamanda birer koleksiyon malzemesine de dönüşmeye başladı. Avusturya hükümetinin lületaşından vergi almaması, Viyana’yı bir lületaşı işleme merkezine dönüştürmüştü. 19. Yüzyıla kadar lületaşı ticareti neredeyse Avusturyalıların elindeydi. Daha sonraları Almanya, Çekoslovakya, Belçika, Fransa, Bulgaristan gibi ülkelerde de lületaşı ticareti ve işlemeciliğiyle uğraşan firmalar kuruldu. Bilim (1991)

\section{Eskişehir'de Lületaşı İşlemeciliğinin Başlaması}

Lületaşı işiyle uğraşanlar; madenciler, taşı işleyenler ve lületaşı tüccarları olarak üç grup altında toplanabilir. Lületaşı madenciliğinin iki ayağı vardır. Bunlar ocak sahipleri ve ocakta çalışan işçilerdir. Lületaşı ocağı işletmeciliği Osmanlı İmparatorluğu zamanında devlet tekelindeydi. "Bu işletmeler ya bir mütesellime emanete verilerek işletilmekte veya bir mültezime verilerek iltizam şeklinde işletilmesi sağlanmaktaydı" Bilim (1991).

Eskişehir'de 1890 'lı yıllarda lületaşı işlendiği bilinmektedir. Üretilen objeler, genellikle küçük parçalardan oluşturulan ve tornada yapılan tespih, kolye vb. gibi parçalardı. Pipo işlemeciliği yapıldığına ilişkin yazılı kaynağa ulaşılamamıştır. Ancak düz pipoların yapıldığına ilişkin rivayetler vardır.

Eskişehir'de Cumhuriyet döneminde lületaşı işlemeciliğini başlatan kişinin 1920'li yıllarda Ali Osman Denizköpüğü olduğu konusunda araştırmacılar hemfikirdir. Denizköpüğü soyadı, İtalyada bir yarışma sonrasında kazandığı ödül dolayısıyla kendisine verilmiştir. Eski lületaşı ustaları, Ali Osman Denizköpügü̈nün lakabının “Kral” olduğunu söyler. 


\section{Lületaşının Yarı Mamul Hale Getirilmesi}

Lületaşının işlenmesinde iki aşama vardır. Bunlar yarı mamul ve mamul hale getirmektir. Yarı mamul hale getirmenin aşamaları şunlardır: Çırpma işleminde, ocaktan çıkartılmış taş sivri ağızlı bir çekiçle çevresindeki diğer taşlardan arındırılır. Kabaca taşın biçimi ve büyüklüğü ortaya çıkartılır. Saykal işleminde, taş tarha (bir tür kısa nacak veya satır) ile üzerindeki yabancı maddelerden ve çamurundan temizlenir. Bu aşamadan sonra taş, Eskişehir içinde işlenecekse ustaya adet hesabıyla satılır. Kabanın alınması işleminde, kaba bıçağı ile taşın üretim için uygun olmayan kısımları, girintileri, çıkıntıları temizlenir. Ocaktan çıkan taşlarda, kimi zaman çatlaklar olur. Bu çatlaklar bazen derinlere kadar gider ve taşın bir bütün olarak işlenmesini engeller. Eğer çatlak derinlere işliyorsa, taş parçalanır ve daha küçük ürünlerde kullanmak için sınıflandırılır. Arış işleminde, kabası alınmış taş, arış bıçağı ile düzlenir, kabanın alınması işleminden sonraki girinti ve çıkıntılar düzeltilir. Perdahlama işleminde çok ince ve keskin ağızlı bir bıçakla taş düzeltilir. Bu işlem bıçakla yapılan son işlemdir. Bundan sonra taşın tandırlanması ve parlatılması işlemine geçilir.

Taşın tandırlanması mevsimine göre değişiklik gösterir. Özellikle kış aylarında perdahlanmış taşlar bir odadaki raflara dizilerek soba yakılır ve kurutulurdu. Yaz aylarında ise bu kurutma işlemi genellikle dükkânın önünde veya avlusunda güneş altında yapılırdı. Son yıllarda tandırlama için, elektrikli fırınlar kullanılmaktadır.

Tandırlanıp iyice kurutulan, bir başka deyişle içindeki tüm suyu atan taşlar, sıcak su ile ıslatılmış keçe veya kalın yünlü kumaş ile ovularak üzerlerinde perdahlama işleminden sonra kalan çizgiler yok edilir. Bu işlem ıslak aba olarak adlandırılır. Bu işlemden sonra taş yünlü bir bez ile tekrar ovulur. Bu işlem ovma olarak adlandırılır.

Ovma işleminden sonra kadife benzeri veya pamuklu bir bez balmumuna batırılır. Balmumuna batırılmış bez ile taşlar tekrar ovulur. Bu işlem, yağlı aba olarak adlandırılır. Bu işlemden sonra taşlar kuru, yumuşak bir bezle iyice parlatılır. Parlatma işlemi sınıflandırma ve sandıklamadan önceki son aşamadır. Bu işlemden sonra taşlar boy ve kalitelerine göre sınıflandırılır eğer ihracatı yapılacaksa pelür kâğıtlara sarılarak ve pamukla desteklenerek sandıklanır ve ihraç edilirdi. Sandıklar tabut olarak adlandırılırdı ve ölçüleri şöyleydi:

\begin{tabular}{|c|c|c|c|}
\hline & Boy & En & Yükseklik \\
\hline Sıra Malı için & $71 \mathrm{~cm}$ & $17 \mathrm{~cm}$ & $34.5 \mathrm{~cm}$ \\
\hline $\begin{array}{c}\text { Pamuklu } \\
\text { Birimbirlik için }\end{array}$ & $71 \mathrm{~cm}$ & $16.5 \mathrm{~cm}$. & $34.5 \mathrm{~cm}$ \\
\hline Dökme için & $80 \mathrm{~cm}$ & $17 \mathrm{~cm}$ & $35.5 \mathrm{~cm}$ \\
\hline
\end{tabular}

Tablo 4: İhracatta kullanılan sandikların boyutları

Ham lületaşı ihracatının yasaklandığg 1972 yılına dek her yıl milyonlarca dolarlık lületaşı ihracatı yapılmaktaydı. Ham lületaşı ihracatının yasaklanması Eskişehir lületaşı sektöründe de sonun başlangıcı olmuştur. Yapılan görüşmelerde edinilen bilgilere göre, bir anda yaklaşı 15 
bin kişinin işsiz kalması Avusturya hükümetini harekete geçirmişti. O yıllarda taş ihracıyla uğraşanlar; "Bir bavul ham lületaşı getirene neredeyse Avusturya vatandaşlığı verilecekti” diyerek durumu açıklamıştı. Türkiye'den kaçak taş ile Viyana’ya gidenlere gümrüklerde herhangi bir sorun çıkartmadan Avusturya’ya girmelerine izin veriliyordu. Bugün Avusturyảda lületaşı işlediğini söylenen bir tek pipo firması kalmıştır. Yaklaşık 100 yıllık geçmişe sahip olan bu firma, muhtemelen yasal yollarla Tanzanya ve Somaliden ve Türkiye'den kaçak olarak elde ettiği taşları ve preslenmiş lületaşlarını işlemektedir.

Lületaşından yapılan ilk objelerin pipo olduğu konusunda araştırmacıların hemen hemen tümü hemfikirdir. Türkiye'de, lületaşından üretilen pipolar beş ana başlık altında incelenebilir. Bunlar; 1. Düz Pipolar, 2. Kabartma Başlı Pipolar, 3. Düz işlemeli pipolar, 4. Saksafon pipolar, 5. Kadın pipolarıdır.

Eskişehir 1960-1980 yılları arasında lületaşı işlemeciliğinin altın çağlarını yaşamıştı. Yukarıda da değinildiği gibi, 1972 yılında ham lületaşı ihracatının yasaklanması ile Viyana’da yaklaşık 500 civarında atölyenin kapandığı söylenmektedir. Viyana’da, kaba bir hesapla 10 bin civarında pipo işleme ustası işi bırakmak zorunda kalmıştı. Viyana pipo endüstrisi buna kısa sürede ayak uydurdu ustalar ahşap pipo üretimine yöneldiler ve tüm dünyada satılan lületaşı pipoların önü de kesilmeye başlandı. Ancak aynı zamanda, çoğu Viyana’da olan pipo firmalarının bir kısmı üretimlerini Eskişehire kaydırıp burada pipo yaptırmaya başladılar. Bu dönemde çok yetenekli pipo işleme ustaları yetişti. Viyanalı tüccarların istedikleri motiflerde pipolar işlenmeye başladı. Viyanalı tüccar söz konusu işlenen pipoları satın alırken, oldukça titiz davranıyordu. Beğenilmeyen pipolar ise başta turistik bölgeler olmak üzere yurtiçinde satışa sunuluyordu.

Yukarıda da değinildiği gibi Viyana pipolarının kopyaları olarak başlayan lületaşı işlemeciliği, bir süre sonra sadece belli modellerin tekrarlandığı bir endüstriye dönüştü.

"Cumhuriyet döneminden itibaren işe koyulan Eskişehirli Lületaşı ustalarının uzun süre; hiçbir tecrübe ve görüşe sahip olmadan, Avrupa modelleri kopye ederek çalışmalarını, bunun sonucunda ortaya çıkan model karmaşası ve yakın zamana kadar aşılamayan kısırlı̆̆ı yadırgamamak gerekir" Ürersoy (1990).

Lületaşı bugünlerde kan kaybetmektedir. Sonuç olarak şu söylenebilir. Bir dönem altın çağını yaşayan lületaşı günümüzde ciddi sorunlarla karşı karşıyadır. Söz konusu sorunlar zaman içinde azalacağına artarak devam etmektedir. Lületaşının geçmişteki altın çağg sona ermiştir.

\section{Avrupa ve Amerika'da Yapılan Pipoların Konuları}

Türk pipoculuğu veya daha doğru bir terimle Eskişehir pipoculuğu ve Avrupa - Amerikan pipoculuğu (Batı pipoculuğu olarak söz edilecektir) arasındaki en önemli ayrım işlenen pipoların konuları arasındadır. Yukarıda da sözü edildiği gibi Eskişehirli pipocular 8-10 klasik konu arasına sıkışıp kalmıştır ve bunların hemen hemen tümü başta Viyana’da üretilenler olmak üzere Batı pipoculuğunun kopyalarıdır. 
Batılı pipolarda insandan hayvana, tarihi olaylara, av sahnelerine, erotizme, oryantalizme, mesleklere dek kısacası akla gelebilecek tüm konularda eserler üretilmektedir. Neredeyse sınır yoktur. Batıda işlenmiş her bir lületaşı eser minyatür bir heykel olarak düşünülebilir. Rönesans’in da etkisiyle gelişen Avrupa heykel sanatı yansımalarının bir kısmını da lületaşında buldu. İşlenmesi kolay, olabildiğince plastik olan bu madde artık sanatçların hayal güçleriyle sınırlıdı.

Lületaşı sanatçlları, doğadan, tarihe, mitolojiden, savaşlara, sosyal yaşamdan, spora, insanlara, insan ırklarına, hayvanlara, bitkilere, erotizme, devlet adamlarına kısaca akla gelebilecek her konuya ilişkin binlerce farklı eser ürettiler. Söz konusu çeşitliliği Eskişehirli ustaların işlediği lületaşlarında görememekteyiz. Bunun temel nedenleri arasında lületaşı işlemeciliğinin Eskişehir'de biraz el becerisi, biraz da yeteneğe göre ve usta - çırak ilişkisiyle öğrenilmesidir. Usta - çırak ilişkisinin de geleneksel lonca veya Ahilik sistemine göre yürütüldüğü söylenemez.

\section{Lületaşı Mamulleri}

Lületaşı işlemeciliği öğrenilebilen bir iştir. Bazı lületaşı işlemecileri basit, örneğin bir kaplumbağa vb. gibi biblo veya basit süs eşyaları yaparken, bazıları ise kendilerine verilen bir fotoğraftan üç boyutlu bir heykelcik oluşturabilmektedirler. Ancak Eskişehirli ustaların büyük çoğunluğu neredeyse çocukluk veya gençlik yıllarından beri "ezberledikleri” beş- on konu dış1na pek çıkamamaktadır.

Lületaşı işlemeciliği, basit el aletleri ve her ustanın kendisinin yaptığı bıçaklarla gerçekleştirilen bir zanaattır. Bir lületaşı işleme ustasının kullandığı aletler tarha, kaba bıçak, iş bıçağı, sıyırgı, göz kalemi, iskarpela, kılavuz, matkap, eğe gibi aletlerdir. Tarha bir tür küçük nacaktır. Lületaşının çamurunu, taşını, toprağını temizlemeye yarar. Diğer bıçaklarsa taşı işlemede kullanılır, örneğin sıyırgı son düzeltmeler ve tesviye yapmada kullanılır.

Bir lületaşı obje imal etmenin iki aşaması vardır. Bunlar a) Yaş İşçilik b) Kuru İşçilik olarak adlandırılır.

\section{Preslenmiş Lületaşı}

Eskişehirde lületaşı sektöründe en çok tartışılan konulardan biri preslenmiş lületaşı kullanımıdır. Lületaşı ürünlerin imalatı ve satışına ilişkin herhangi bir yönetmelik vs. bulunmadığ için, blok lületaşı, preslenmiş lületaşı, alçıyla karıştırılmış lületaşı tozları gibi doğal veya suni yöntemlerle elde edilmiş lületaşı ve benzerlerinin işlenmesine ilişkin düzenlemeler de yoktur.

Öncelikle şu konuların açıklığa kavuşturmak yerinde olabilir.

1. Lületaşı sektörü var olduğu sürece, ocaktan çıkartılıp, doğrudan ustalar tarafından işlenen ve blok lületaşı olarak adlandırılan taşlar ve bunların artıklarından ve daha düşük kaliteli taşların ögütülüp, belli kimyasal maddelerle karıştırılmasından elde edilen preslenmiş lületaşı kullanımı konusundaki tartışmalar hep devam edecektir.

2. Lületaşının en küçük zerresine kadar değerlendirilmesi bölge ekonomisine kuşkusuz katkılar sağlayacaktır. O yüzden preslenmiş lületaşının farklı objelerin yapımında kullanılması da çok doğaldır. 
3. Blok lületaşı ve preslenmiş lületaşı arasındaki ayrım, yönetmeliklerle net biçimde ortaya konmalıdır.

4. Lületaşı ürünler, bu ister 2-3 TL’ye satılan bir magnet olsun, isterse değeri binlerce doları bulan bir pipo olsun, mutlaka sertifikalandırılmalıdır. Söz konusu sertifikada, lületaşı objenin blok mu veya preslenmiş lületaşından mı yapılmış olduğu net olarak belirtilmelidir. Avusturya'da üretilmiş pipolar için bu tür sertifikalar vardır.

5. Sertifikada taşın niteliğinin yanı sıra, hangi bölgenin taşı olduğu, hangi usta tarafından işlendiği gibi bilgiler de yer almalıdır.

6. Preslenmiş lületaşının küçük hediyelik objelerin yapımında kullanılmasının yararlı olabilir.

Yüksek kaliteli lületaşlarının işlenmesinden artan toz, talaş ve kırpıntının miktarı azımsanamaz. Zaman zaman bu miktar bir "pamuklu" taşta \%30-35 oranlarına dek ulaşabilir. 1966 yılında, günümüzden 46 yıl önce Eskişehir Ticaret Odası Meslek Komitesinin yaptığı bir araştırmada ve Eskişehir Sanayi Müdürlüğü tarafından yürütülen çalışmada yıllık yaklaşık 40-50 ton civarında toz, talaş ve kırpıntının açığa çıktığı belirlenmiştir. O günden günümüze dek bu konuda yapılmış başka bir çalışma yoktur.

\section{Preslenmiş Lületaşı ve Kullanım Yerleri}

Yukarıda da söz edildiği gibi işlenen ham taşın yaklaşı \%30'luk bir bölümü fire olarak karşımıza çıkmaktadır. Bunun dışında ikinci ve üçüncü kalite sayılabilecek ve pipo imalatında kullanılmayan "cılız" taşlar da ögütüldükten sonra belli işlemlerden geçirilerek farklı ürünlerin elde edilmesinde kullanılabilir.

Gerek ham lületaşının zaman içinde pahalılaşması, gerekse lületaşı ihracatının yasaklanması batıda farklı arayışların başlamasına neden olmuştu. Bununla ilgili olarak "suni lületaşı", "kültür lületaşı”, gibi adlar verilen, düşük kaliteli lületaşlarının toz haline getirilmesinden sonra belli kimyasal maddelerle sıkıştırılmasıyla lületaşı benzeri malzemeler oluşturulmuştur.

\section{Pipo Astarlar1}

Ahşap pipoların tütün haznelerine preslenmiş lületaşından yapılmış pipo astarları konur. Pipo astarları hem ahşabın ısınmasını önler hem de kısmen nikotin fazlasını emer. O yüzden lületaşı astarlar pipo imalatçıları tarafından tercih edilir. Suni lületaşı ilk önceleri ahşap pipoların iç kısmına yerleştirilen astarların yapımında kullanılmıştır.

Günümüzde Eskişehirde pipo astarı yapan firma kalmamıştır.

Değişik pipo türlerine göre değişik boyut ve türlerde astarlar yapılır. Lületaşı astarları standarttır. Belli ölçülerde preslenen astarlar kuruduktan sonra torna tezgâhında standart ölçüye getirilir.

\section{Lületaşı Sektörünün Sorunları ve Çözüm Önerileri}

1980’lere kadar altın devrini yaşayan Eskişehir lületaşı işlemeciliği, bu dönemden sonra hızla 
kan kaybetmeye başlamıştır. Bir zamanlar milyon dolarlarla ölçülen ihracat miktarı, günümüzde neredeyse yok düzeyine gelmiştir. Lületaşı sektöründe birçok sorun bulunmaktadır. Ancak bunlar, bugünün değil, geçmişten günümüze dek gelen sorunlardır. Sektördeki sorunlar beş ana başlık altında toplanabilir.

Bunlar; a) Ham taş üretimi ve madencilik, b) Lületaşının işlenmesi, c) Eğitim ve yeni ustaların yetiştirilmesiyle, d) Lületaşının pazarlanması ve e) Örgütlenme sorunlarıdır.

Değişen tütün kullanma kültürü ve daha sonra tütüne karşı dünyanın birçok yerinde başlayan tepkiler lületaşının tütüne yönelik objelerin üretiminde kullanılmasını da azaltmıştır.

Eskişehir'de şu an kaç ocağın çalıştığını, bu ocaklarda çalışan insan sayısını belirlemek zor görünmektedir. Lületaşı madenciliğiyle uğraşan kişiler ya kaçak ocak açmaktadır veya daha önce kullanılmış ocakları temizleyerek yeniden kullanma yoluna gitmektedir. Lületaşı arama ve maden işletme ruhsatlarının belli ellerde toplanması, yüzyıllardır lületaşı çıararak geçinen madencilerin zor durumda kalmalarına, kaçak kazılara yönelmelerine, eski kuyuları temizleyerek lületaşı aramalarına neden olmaktadır. Lületaşı madenlerinde çalışan bölge halkının önemli bir kısmı bu işi tarımdan arta kalan zamanda yapmaktadırlar. Bu da beraberinde işçilik sorununu getirmektedir. Madenlerde çalışan işçilere ödenen ücretler düşüktür ve sosyal güvenceleri de yoktur.

Maden sahalarının işletilmesi 5177 Sayılı Kanunla Değişik 3231 Sayılı Maden Kanunu’na göre yapılmaktadır. Bölgede var olan Lületaşı madenleri, şahıslar veya şirketler adına ruhsatlıdır veya bulunmuş maden olarak aramalara kapalıdır. Bozkurt (1989b) Bu alanlarda lületaşı çıkartmak için çalışma yapmak isteyenler, maden sahaları büyük ölçeklerde belli kişi ve firmalar tarafından kapatıldığı için kuyu açamamaktadır. Kuyu açılsa bile maliyetler oldukça yükselmiştir. Günümüz rakamlarıyla, bir ocağın açılması, yaklaşık 120-200 bin Euro arasındadır.

Lületaşı madenciliği hem Eskişehir lületaşının kalitesi hem de lületaşına olan dış talep dolayısıyla, oldukça gelişmişti. Ancak Eskişehir'de işlenen taşların, Avrupa veya Amerika'da işlenenler kadar üstün nitelikli, estetik ve kaliteli oldukları söylenemez. Bunun temellerinde eğitim, heykel geleneği olmayan bir ülke olmamız, ciddi bir sanat eğitimi olmaması gibi nedenler yatmaktadır.

Bunun dışındaki en önemli sorunlardan biri de "lületaşında konu" dur. Batıda üretilen lületaşı pipo ve diğer ürünlerde konu sınırı neredeyse yoktur. Batılı lületaşı pipo sanatçıları hayal güçlerini sonuna dek kullanarak çok farklı objeler üretmişlerdir.

\section{Eğitim Sorunları}

Sektörde, yeni ustalar yetişmemekte veya lületaşı işlemeciliğini bir meslek olarak görenlerin sayısı gün geçtikçe azalmaktadır. Endüstrinin bir kolu olmasına karşın diğer mesleklerde olduğu gibi, lületaşı işlemeciliğinin bir okulu olmamıştır. Olanlar da yaşamlarını idame ettirememiştir. Lületaşı işlemeciliği usta çırak ilişkisiyle öğrenilen bir meslek olmuş, en azından günümüze dek öyle sürüp gitmiştir. Günümüzde Eskişehir'de sayıları oldukça azalmış olsa da lületaşı işleyen bir grup usta bulunmaktadır. Bu ustalar mesleklerinin son temsilcileridir ve arkada yetişen yeni 
ustalar olmadığı için de bu meslek zaman içinde yok olup gidecektir. Gerek maddi koşullar, gerekse gençlerin bu işi yapmak istememeleri yeni ustaların yetişmesini engelleyen önemli faktörler arasındadır. Daha önceki okul denemelerinin başarısızlıkla sonuçlandığı düşünülürse, yeni kurulacak sistemin doğru analizlerinin yapılarak oluşturulması zorunludur. Böylesi bir okulda sadece lületaşını işleyebilmek değil, aynı zamanda mesleklerini sürdürebilmeleri için gereken temel sanat eğitimi, resim, teknik resim, temel madencilik ve taş bilgileri, sanat tarihi, mitoloji vb. gibi bilgiler, dertlerini anlatabilecek veya satışlarını yapabilecek kadar yabancı dil bilgisiyle de donatılmalıdırlar. Lületaşı eğitimi yalnızca bu okul veya merkezle sınırlı kalmayabilir. Örneğin; Güzel Sanatlar, Kız Meslek Liseleri gibi okullardaki gençlerden ilgili olanlar sözü edilen okulda eğitilebilirler.

Eğitimle ilgili önemli bir katkı da Eskişehir'deki üniversitelerden gelebilir. Üniversitelerin Güzel Sanatlar Fakülteleri ve Tasarım bölümlerindeki gençlerden istekli olanlar da lületaşı işlemek üzere yetiştirilebilir. Böylesi bir girişimin lületaşı işlemeciliğine farklı bir görüş gelebilir.

Lületaşı işlemeciliği sosyal ve kültürel yaşama sonradan giren bir meslek olduğu için, Osmanlı’nın Ahilik ve lonca teşkilatlarının geleneklerinden de yararlanamamıştır. Bilindiği gibi Ahilik ve lonca sistemlerinde çıraklıktan sonra, kalfalık ve ustalık mertebelerine ulaşmak için mesleki ve sosyal anlamda ve alanlarda belli aşamalardan geçilmesi gerekiyordu. Bu aşamaların her birine ulaşma ise belli kurallara bağlanmıştı. Mesleki etik kuralları oluşturulamamıştır. Kalfalığa ve ustalığa yükseltilme işleri, belli kurallara bağlanamamıştır. Bir usta yanında veya bir şirkete bağlı olarak çalışanların sosyal güvenceleri ve diğer hakları net değildir.

Kanımızca, lületaşı işlemeciliği bazı kaynaklarda değinildiği gibi bir halk sanatı değildir. Lületaşı her ne kadar Eskişehire mal olmuş bir zanaat olarak görülse de halk tarafından benimsenmemiştir. Dolayısıyla UNESCO tarafından tanımlanan "halk sanatı" veya "somut olmayan kültürel miras” tanımlarına uymamaktadır. Lületaşı işlemeciliği maden/değerli taş işleme endüstrinin bir kolu olarak kabul edilmelidir.

Günümüzde formlar giderek birbirini tekrarlayan, birbirinin aynı hale gelmiştir. Pipolar nerdeyse aynı formları taşımakta, ağızlık, takı ve benzerleri birbirlerinin aynı olmaktadır. Her lületaşı parçasının pipo olması gerekmemektedir. Estetik değeri yüksek heykelcikler, biblolar üretilebilir. Üretilen her parça koleksiyon parçası olarak düşünülebilir. Böylelikle, örneğin; bir parçası 50-60 dolara satılan bir pipo yerine, koleksiyonerlere yüzlerce dolara satılan sanat eserleri oluşturulabilir. Yeni form ve arayışlar kanımızca lületaşında kaybolmakta olan ilginin artmasını da sağlayacaktır.

Geçmişi yüz yılı aşmış bir Ticaret Odası, güçlü bir Sanayi Odası, iki üniversitesi olan bir kentte, Eskişehir'in simgelerinden biri olan lületaşıyla ilgili bir “Araştırma Merkezi”nin olmaması kanımızca bir eksikliktir. Günümüz piyasa koşullarında küçük sayılacak maddi desteklerle ve üniversitelerdeki bilgi birikimi ve eşgüdümle bu sağlanabilecek bir olanaktır ve kuşkusuz gerek Eskişehir halkının gerekse dünyanın lületaşına bakışını etkileyebilecektir.

Yüzyıllar boyunca pipo, lüle, nargile ile tüketilen tütün, özellikle Birinci Dünya Savaşı sonra- 
sında yoğunlukla sigara biçiminde tüketilmeye, İkinci Dünya Savaşı sonrasında ise, neredeyse tümüyle sigara biçiminde tüketilmeye başlanmış, pipo kullanımı oldukça azalmıştır. Pipo günümüzde gündelik yaşamda çok az kullanılan bir obje haline gelmiştir. Günümüzde kaliteli lületaşı pipolar sadece bir koleksiyon ürünü haline dönüşmüştür.

Orta kalitedeki 20-50 Amerikan Doları arası satılan (1 Dolar = 2.6 TL., 2015 ilk altı ay) pipolar ise daha çok Eskişehire ziyarete gelen günübirlik turistler tarafından anı veya hediye olarak satın alınmaktadır.

Lületaşı mamulleriyle ilgili standartlar oluşturulamamıştır. Pazarlamaya ilişkin sayısız sorun vardır. Eskişehir'de bulunan, çoğu ihracatçı, anlaşabilecek veya yazışmalar yapabilecek düzeyde yabanc1 dil de bilmemektedir.

Lületaşçıların mesleki anlamda örgütlenmeleri ancak 1950'ler sonrası olmuştur ve farklı çatılar altında, örneğin; Ticaret Odası, Esnaf ve Sanatkârlar Dernekleri veya dernekler altında toplanmışlardır ve bu dağınıklık günümüzde de sürmektedir.

Eskişehir'de, Esnaf ve Sanatkârlar Birliği bünyesinde bir Lületaşçılar Odası mevcut iken günümüzde bu oda kapanmış. Lületaş̧̧lar mevcut yasa gereği, kendilerine en yakın (!) işi yapan Saatçiler Odası’na bağlanmıştır. Şu an lületaşı esnafı Saatçiler Odası̉nın bir kolu olarak faaliyet göstermektedir ve kayıtlı 47 üyesi vardır. Ayrıca Eskişehir Ticaret Odası’na kayıtlı görünen lületaşı esnafı sayısı 49'dur ancak bu firmalardan sadece 15'i yasal olarak faal görünmektedir ancak yaptığımız araştırmada sayının 10 civarında olduğu belirlenmiştir.

Eskişehir'de hali hazırda üç tane lületaşı ile ilgili dernek bulunmaktadır. Bunlar Lületaşı El sanatları Derneği, Lületaşı Sanatkârları Eğitim, Kültür Sosyal Dayanışma ve Yardımlaşma Derneği, Lületaşı Derneği (Lüle-Der). Bunun dışında 49 üyesi olan "Lületaşı ve Diğer Değerli Taşlar İşletme Kooperatifi“ kurulmuştur. Ancak bu kooperatif birkaç yıllık geçmişine rağmen günümüzde atıl durumdadır.

Kooperatif üyeleriyle yaptığımız görüşmelerde, kooperatifin kurucuları ve üye olanlarından bile, "İşin dışında kalmamak için kooperatife katıldık..., "Bir faydası olacağını düşünmüyorum ama arkadaşlar katılınca ben de katıldım... "Katılım sadece 1000 TLydi. Onu da taksitle alıyorlardı. Onun için katıldım...” ve benzeri yanıtlar aldık. Lületaşçılar daha önce de bir kaç kooperatif deneyimi yaşamışlardır. Hepsi de başarısızlıkla sonuçlanmıştır. Kanımızca bu kooperatif de prematüre olarak doğmuştur. Kooperatif 2011 yılının son aylarında Türkmentokat civarında bir ocak açma girişiminde bulunmuştur. Ancak üretime başlayamamıştır.

Eskişehir dendiği zaman akla ilk geliveren ürünlerden biri olan lületaşına, Eskişehir Sanayi Odası (ESO) tarafından 27 Ekim 1997 tarihinde "coğrafi işaret” alınmak üzere Türk Patent Enstitüsü’ne başvurulmuştur. Türk Patent Enstitüsü ise lületaşını 07 Ocak 1999 tarihinde Eskişehire özgü bir taş olarak tescil etmiştir. 


\section{SONUÇ}

Günümüzde Eskişehir'de sayıları oldukça azalmış olsa da lületaşı işleyen bir grup usta bulunmaktadır. Bu ustalar mesleklerinin son temsilcileridir ve arkada yetişen yeni ustalar olmadığı için bu meslek de zaman içinde yok olup gidecektir. Gerek maddi koşullar, gerekse gençlerin bu işi yapmak istememeleri yeni ustaların yetişmesini engelleyen önemli faktörler arasındadır. 1960'lı yıllardan başlayarak altın çağını yaşayan lületaşı satışları günümüzde gerilemiş, pek çok atölye kapanmış, birçok usta işini bırakmak zorunda kalmış, ihracatçılar da bu işten vazgeçmek durumunda kalmıştır. Üretime ilişkin sorunlara vergilendirme, sosyal güvence, işletme giderleriyle ilgili yükler de eklenince işler neredeyse durma noktasına gelmiştir.

- Ham lületaşı üretiminin artırılmasına yönelik tedbirler alınmalıdır. Taş üreticisinin yasal yollarla üretim yapması sağlanmalı, maden arama, işletme ve taşımayla ilgili konularda yeni ve üreticinin yanında olan düzenlemeler yapılmalıdır.

- Ham lületaşının ihracına yönelik alınmış olan ve 1970'lerden beri uygulanan sınırlama gözden geçirilmelidir. Günümüzde tüm ülkeler dış satımlarını artırmak üzere çalışmaktadır. Böylesi bir yasaklamanın günümüzde ne kadar gerçekçi olduğu bir kez daha gözden geçirilmelidir.

- İşlenmiş lületaşı kalitesi mutlaka artırılmalıdır. Dış pazarların kapanması, üretilen objelerde bir özensizliği de beraberinde getirmiștir. 1970’lerde üretilmiş objelerle kıyaslandığı zaman günümüzde çok ciddi bir kalite sorunu yaşanmaktadır.

- Ustaların ve ustalığa adım atanların farklı eğitimlerden geçmeleri sağlanmalıdır. Eski kuşak taş işleme ustaları onlarca yılın verdiği alışkanlıklarla hep aynı motifler arasına sıkışıp kalmışlardır. Çok isteseler de farklı alanlara kaymada zorluklar yaşayabilirler. Ancak genç ustaların "tütün dışı" üretime yöneltilmeleri daha kolay olabilir.

- Meslek liselerinin, üniversitelerin ilgili bölümlerinden gelen ve lületaşı işlemeye gönüllü/yetenekli, estetik, temel sanat eğitimi, temel tasarım, sanat tarihi vb. gibi sanatsal üretimde önemli olan konulara vakıf gençlerin bu alanda yetiştirilmesi için gerekli girişimlerde bulunulmalıdır.

- İmalatta bir standart söz konusu değildir. Bu ciddi bir sorun olarak ortaya çıkmaktadır. Kullanılan taş kalitesi, işçilik, ambalajlama fiyatlandırma gibi konularda mutlaka bir standartlaşma gerçekleştirilmelidir.

- Sertifikalandırmaya hızla geçilmelidir. Müşteri ne satın aldığını bilmelidir. Sertifikalandırma hem pres lületaşı, alçı vb. konularda yaşanan sorunları sona erdirecektir. Hem de piyasadaki dürüst esnafın ayırt edilmesini beraberinde getirecektir.

- Lületaşına ilişkin tüm kayıtlar ciddi biçimde tutulmalıdır. Bu çalışma sırasında söz konusu kayıtların ciddi biçimde tutulmadığını gözlemlenmiştir. Çalışan sayısından, üretime, ihracat gelirlerinden, rezervlere dek her konuda, resmi kurumlar arasında bile tutarsızlıklar gözlemlenmiştir.

- Geniş̧ ölçekte bakıldığı zaman lületaşı sektörünün ulusal ekonomiye katkısı oldukça küçük boyutlarda görünebilir ancak yerel ölçekte bu katkı yüksek olmaya adaydır. 
- Lületaşı konusuyla uğraşan birimler/kurumlar arasında bir koordinasyon bulunmamaktadır. Oysa taşın ocaktan çıkmasından başlayan ve satış sonrasına dek uzanan işbirliğinin mutlaka tesis edilmesi gerekliydi. Söz konusu koordinasyonun mutlaka kurulması gerekmektedir. 


\section{KAYNAKÇA}

AKINCI Ömer, (1967) "Eskişehir 124-c paftasının jeolojisi ve tabakalı lületaşı zuhurları", MTA Dergisi, Sayı 68, Ankara, 22-23.

ALBEK Suzan, (1999) Dorylaion'dan Eskişehir'e, T.C Anadolu Üniversitesi, Eğitim Sağlık ve Bilimsel Araştırmalar Vakfı Yay. No: 891, Eskişehir.

BİLGEN A.Nejat (Bahar 2006) Çavlum Eskişehir Alpu Ovası’nda Bir Orta Tunç Çağı Mezarlı̆̆l, Elektronik Sosyal Bilimler Dergisi www.e-sosder.com ISSN:1304*0278 C.5 S.16 (17-22), (erişim tarihi 28 Mayıs 2014)

BİLİM Cahit, (1999), “Deniz Köpüğ̈̈, Lületaşı”, Ankara Üniversitesi Osmanl Tarihi Araştırma ve Uygulama Merkezi Dergisi, Sayı:8, Ankara s.91.

BOZKURT, Rifat, (Kasım 1989), "Lületaşı sorunları ve çözüm önerileri”, Anadolu Üniversitesi, İktisadi ve İdari Bilimler Dergisi, Cilt:7, Sayı: 2; Sayfa 193-204.

BOZKURT, M.Rıfat, (Eylül 1989), “Lületaşı (Eskişehir Taşı)”, II. Uluslararası Lületaşı “Beyaz Altın” Festivali, Beyaz Altın Semineri Notlari.

DPT (2001), “Madencilik Özel İhtisas Komisyonu, Endüstriyel Hammaddeler Alt Komisyonu, Diğer Endüstri Mineralleri Çalışma Grubu Raporu, Cilt 1, Lületaşı-Tabakalı Sepiyolit-Atapulgit (Paligorksit), Grafit, Mika, Barit, Talk, Alunit, Zeolit”" T.C Başbakanlık; Devlet Planlama Teşkilatı Müsteşarlı̆̆ı, Yayın No: DPT 2421.

FELLNER, Sabine, THIEL, Georg, (2009) Nikotina, European Smoking Culture, Austria Tabak, Viyana.

MTA (1975), Türkiye Maden ve Diğer Yeraltı Kaynakları Genel Envanteri, Maden tetkik Arama Enstitüsü Yay. No.154, Ankara, 22-23.

RAPAPORT, Ben (1999), Collecting Antique Meerschaum Pipes, Schiffer Publishing Ltd., Atglen.

SİYAHİ, Cem (1989) “Eskişehir Taşı Üzerine Birkaç Söz” II. Uluslararası Lületaşı “Beyaz Altın” Festivali, Beyaz Altın Seminer Notlart.

TAŞLIGİL Nuran, ŞAHİN Güven (Kış 2011) “Doğal ve Kültürel Özellikleriyle Lületaşı”, Uluslararası Sosyal Araştırmalar Dergisi, Cilt: 4, Sayı :16, 45-46.

TEKİN, Cengiz (Haziran: 1972)."Lületaşı ve Ekonomik Değeri”, Eskişehir İktisadi ve Ticari İlimler Akademisi Dergisi, Cilt:8, Sayı: 2, Sayfa: 250-289.

TEKİN; Cengiz (1972). "Lületaşı Sektörünün Ekonomik Analizi” Eskişehir İktisadi ve Ticari İlimler Akademisi, Doktora Tezi.

TEXIER Charles (2002). Küçük Asya Coğrafyası, Tarihi ve Arkeolojisi (Çeviri: Ali Suat), Enformasyon ve Dokümantasyon Hizmetleri Vakfi, Ankara.

TOGAN Zeki Velidi (1946) Umumi Türk Tarihine Giriş, Yayınevi Belirsiz, İstanbul.

TUNÇDÍLEK Necdet (1955). Lületaşı (Meerschaum) Türk Coğrafya Dergisi, Cilt: XII, 13-14.

ÜRERSOY Talat (1990) "Bir Topak Beyaz Taş” III. Uluslararası Lületaşı “Beyaz Altın” Festivali, Beyaz Altın Seminer Notlart. 


\section{FOTOĞRAFLAR}

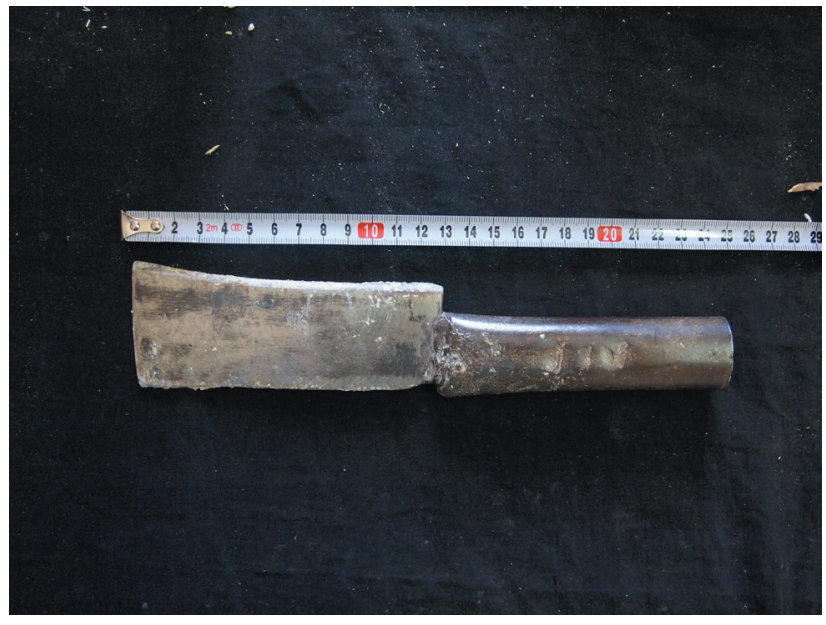

Görsel 1: Tarha

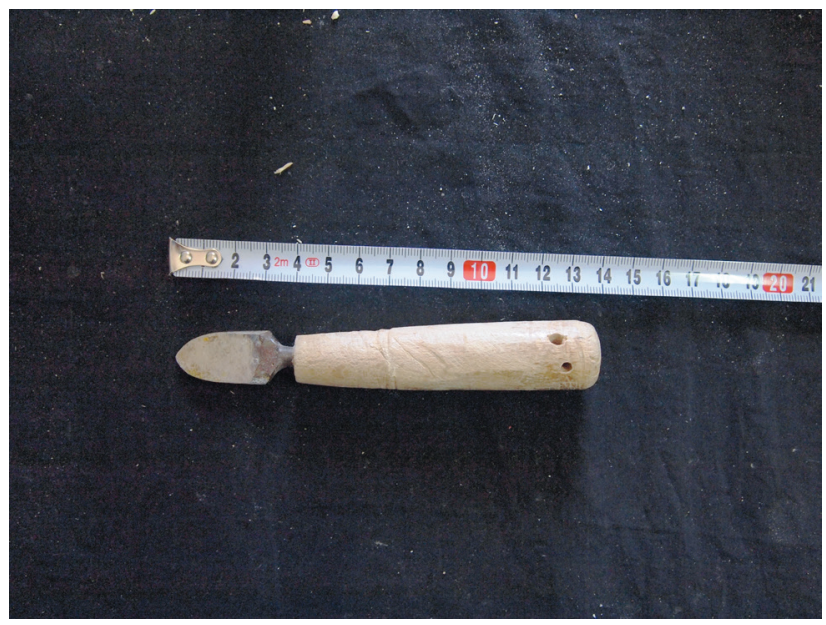

Görsel 2: Tütün Haznesi açma bıçağı 


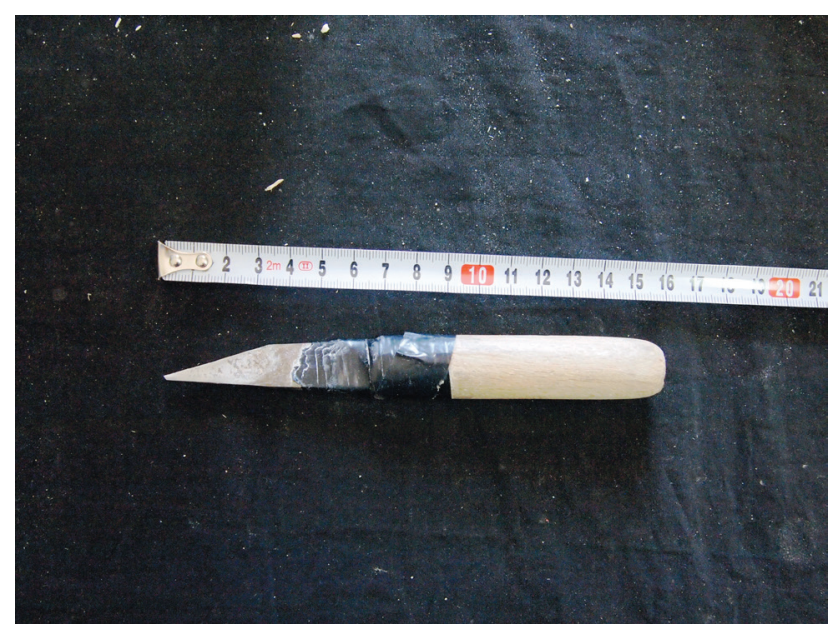

Görsel 3: Bıçak

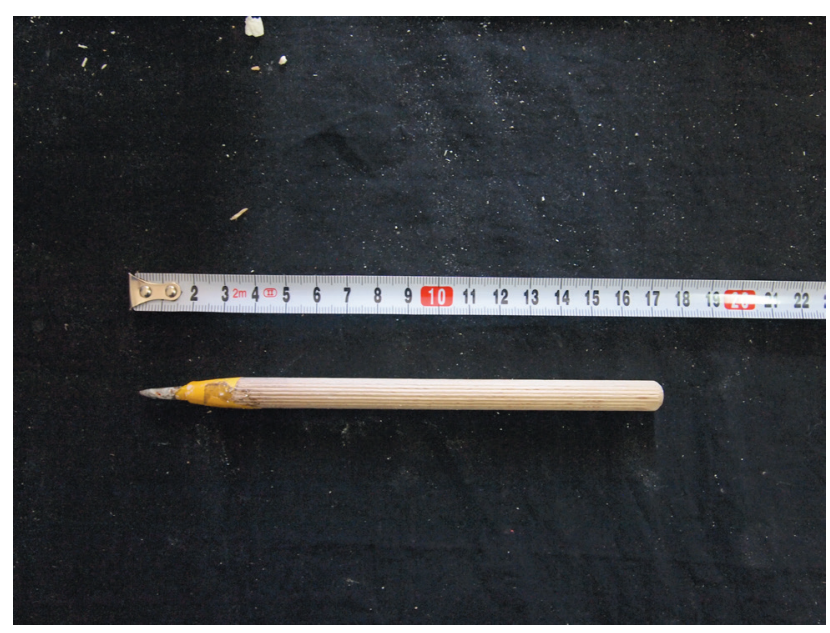

Görsel 4: Göz Kalemi

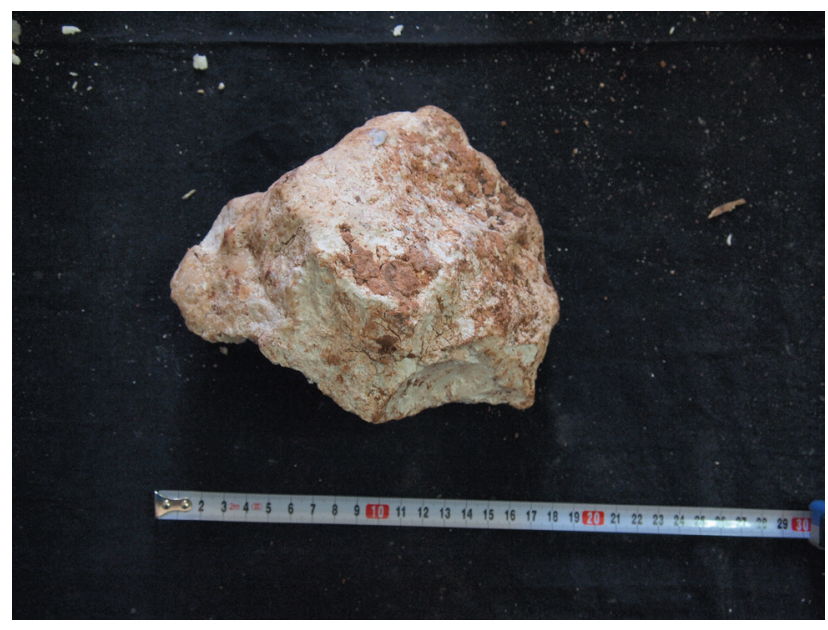

Görsel 5: Ham taş (pamuklu boy) 


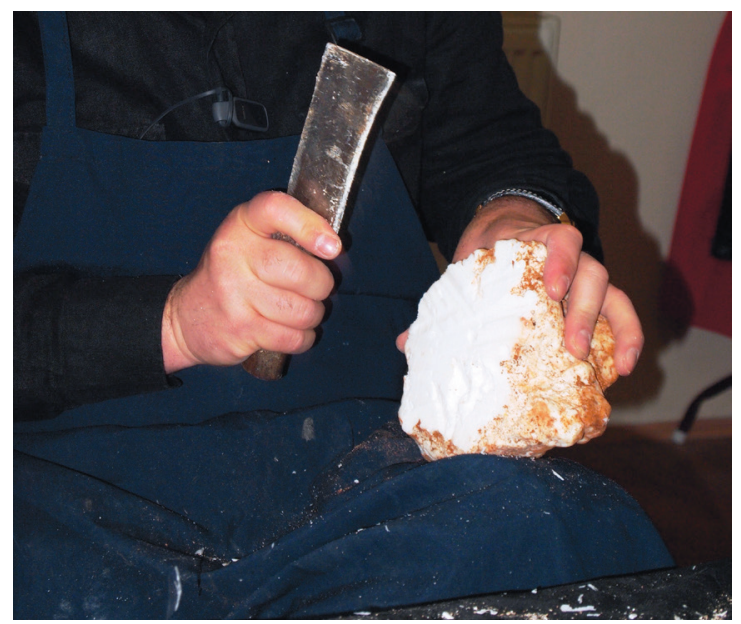

Görsel 6: Ham taşın temizlenmesi

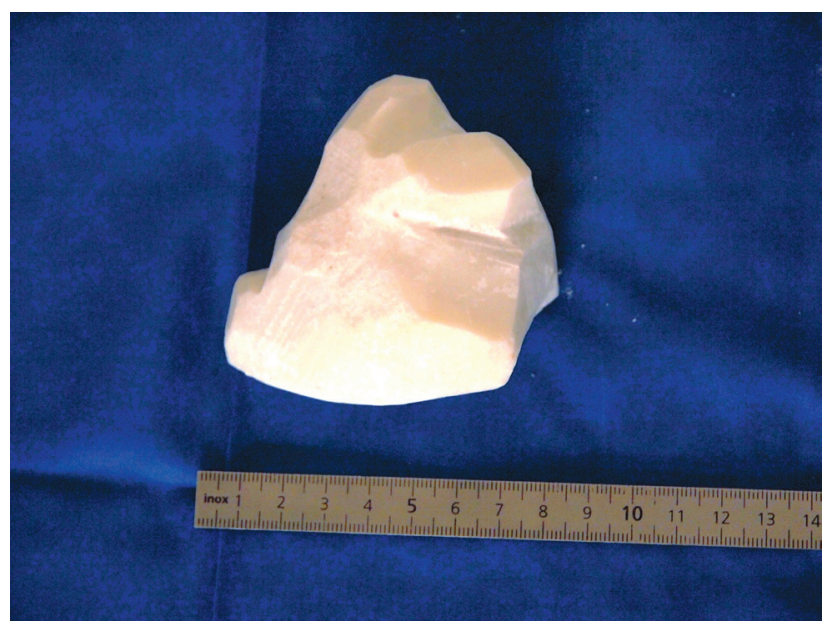

Görsel 7: Üretilecek objeye göre, kabaca biçimlendirilmiş taş

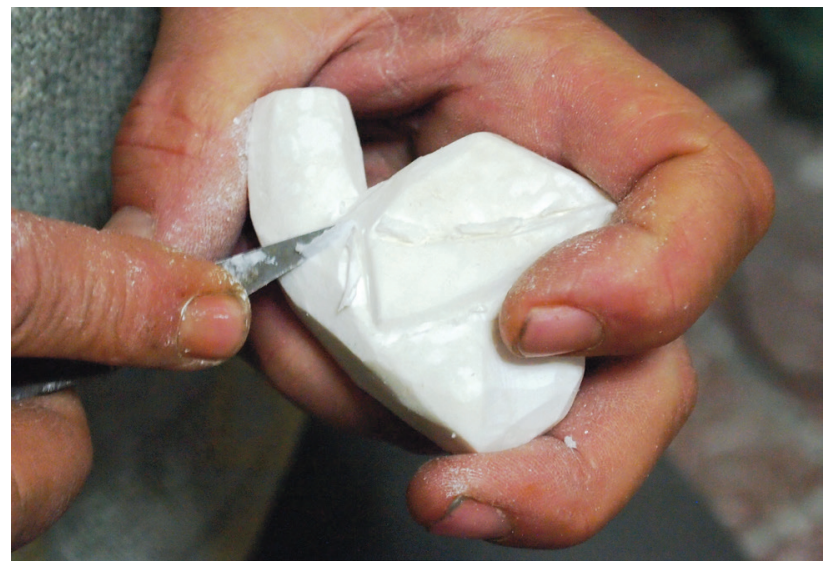




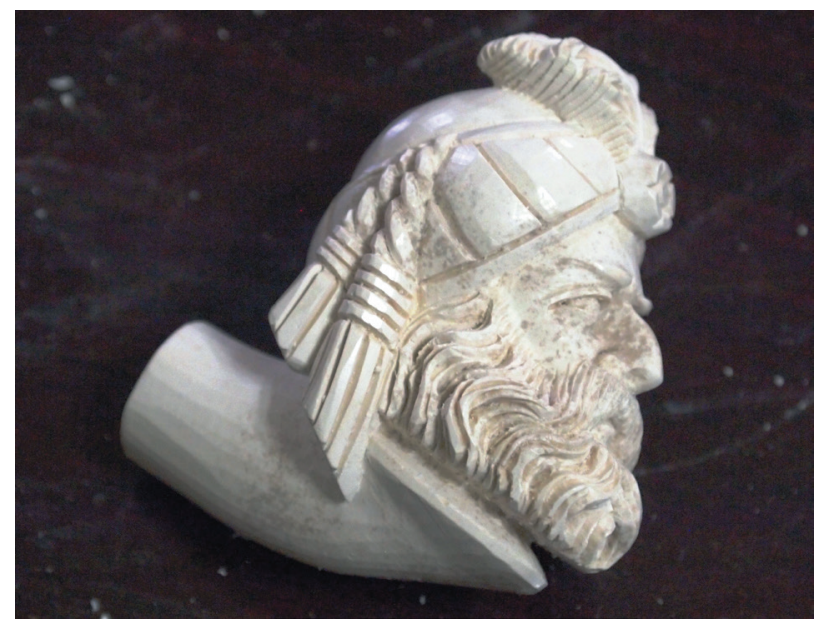

Görsel 9: Biçimlendirilmiş ancak zımparalanmamış ve parlatılmamış obje

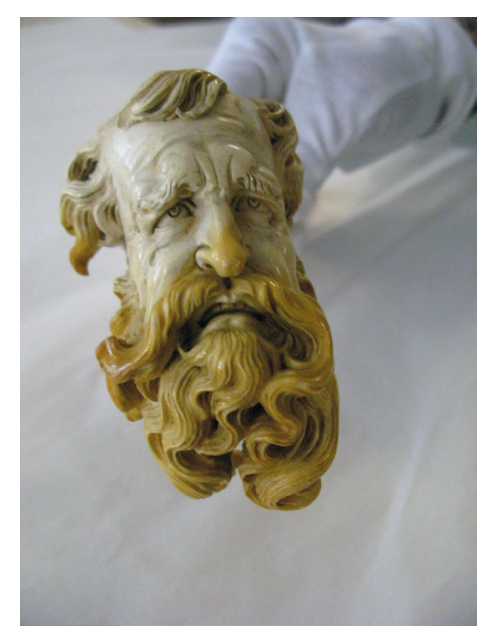

Görsel 10: Avusturya'da işlenmiş bir pipo (Avusturya Tabak Koleksiyonu)

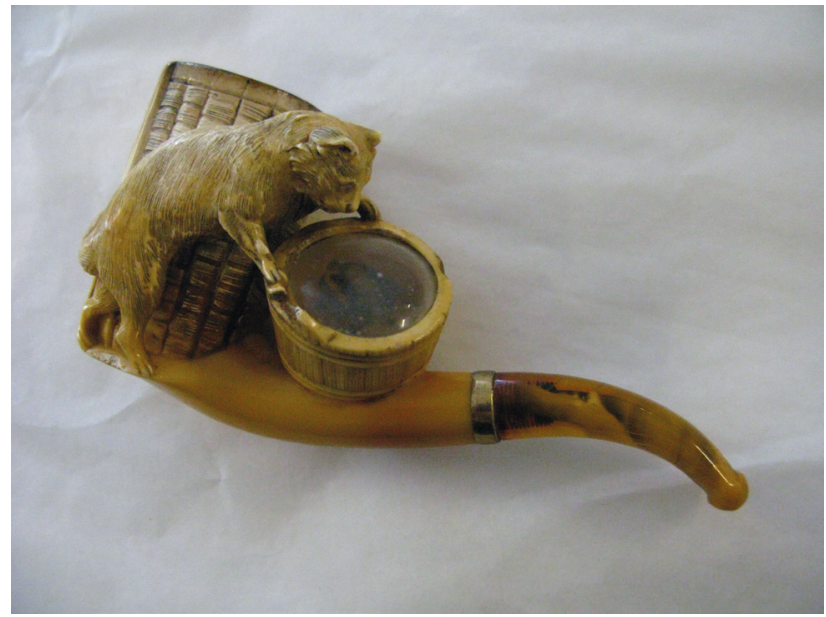

Görsel 11: Avusturya'da işlenmiş bir pipo (Avusturya Tabak Koleksiyonu) 


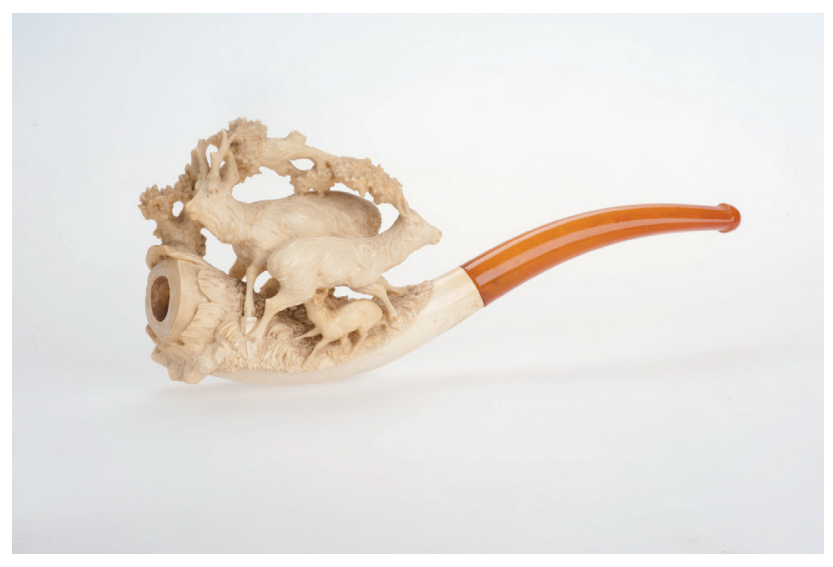

Görsel 12: Avusturya'da işlenmiş bir pipo (Avusturya Tabak Koleksiyonu)

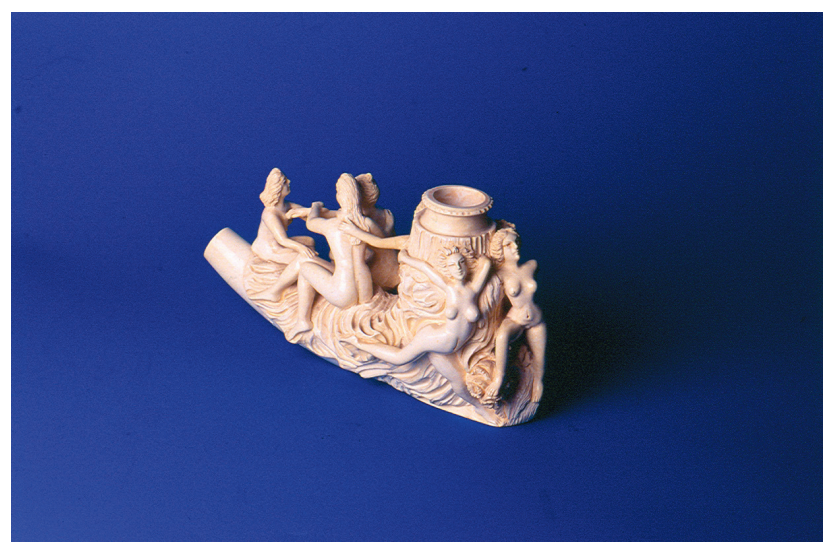

Görsel 13: Eskişehir'de 1970’lerin sonunda işlenmiş bir pipo

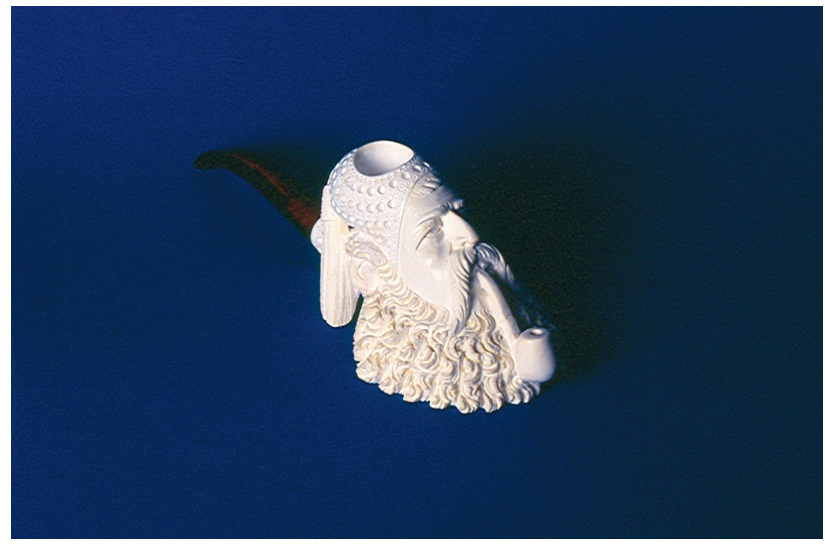




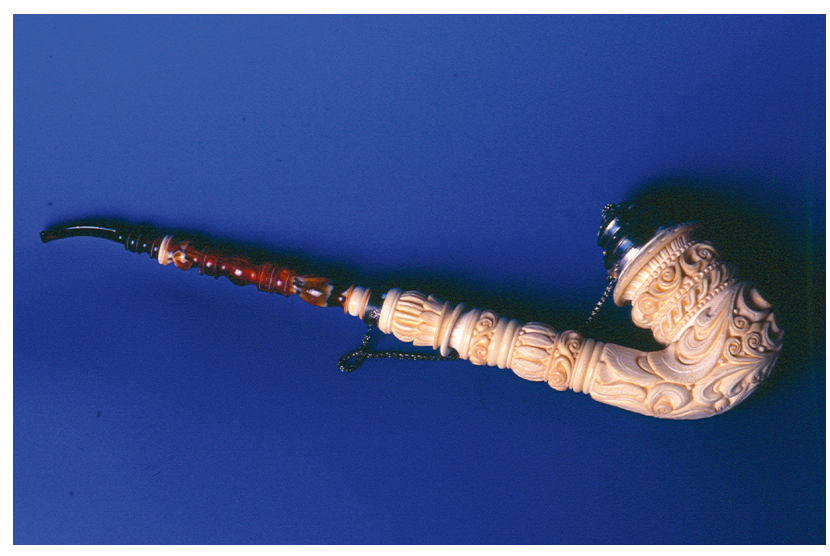

Görsel 15: Eskişehir'de işlenmiş bir pipo 
